\title{
Türkiye'nin Sağlık ve Sosyal Harcamaları: Sosyal Hizmet Perspektifinden Retrospektif Karşılaştırmalı Bir Çalışma
}

Türkiye'nin Sağlık ve Sosyal Harcamaları: Sosyal Hizmet Perspektifinden Retrospektif Karşılaştırmalı Bir Çalışma Öz

1980'li yılların başında sosyal devlet anlayışının azaldığı ve liberal ekonominin kılık değiştirerek neoliberal politikalar adı altında hüküm sürdüğü bir süreç hem gelişmekte olan hem de gelişmiş ülkeler için başlamış oldu. Bu bağlamda, neoliberal politikaların gün yüzüne çıktığı 1980 yılı, Türkiye'ye ilişkin sağlık ve sosyal harcamaların değerlendirilmesinde başlangıç yılı seçilmiştir. Öte yandan, çalışmada sağlık ve sosyal harcamaların seçilmesinin nedeni ise sosyal hizmet bakış açısının Ekonomik Kalkınma ve İşbirliği Örgütü (OECD) verileri kullanılarak yapılacak olan değerlendirmeye yansıtılmak istenmesidir. Dolayısıyla bu çalışmanın amacı Türkiye'nin sağlık ve sosyal harcamalarının sosyal hizmet bakış açısı temelinde OECD verileri kullanılarak retrospektif karşılaştırmalı şekilde incelenmesidir. Bu yönüyle çalışma Türk sosyal hizmet literatüründe ilk karşılaştırmalı retrospektif araştırma olması açısından da önemlidir.

Anahtar Kelimeler: Neoliberal Politikalar, Türkiye, Sağlık Harcamaları, Sosyal Harcamalar, Sosyal Hizmet, Sosyal Hizmet Bakış Açısı.
Turkey's Health and Social Expenditures: A Retrospective Comparative Study from the Perspective of Social Work

Abstract

At the beginning of the 1980 s, when the state of welfare declined and liberal economy disguised, so-called neoliberal politics flourished in both developing and developed countries. In this context, the year 1980, in which neoliberal policies emerged, has been chosen as the initial year for the assessment of health and social expenditures in the case of Turkey. The reason for the selection of health and social expenditures in the study is to reflect the perspective of social work on the assessment to be made using OECD data. In this regard, the aim of this study is to make a retrospective and comparative examination of the health and social expenditures of Turkey using OECD data from the perspective of social work. This study is also important in terms of being the first comparative retrospective research in Turkish social work literature.

Keywords: Neoliberal Policies, Turkey, Health Expenditures, Social Expenditures, Social Work, Social Work Perspective.

\section{Giriş}

Dünyada 1980'li yılların başında sosyal devlet anlayışının azaldığı ve liberal ekonominin kılık değiştirerek neoliberal politikalar adı altında hüküm sürdüğü bir süreç, hem gelişmekte olan hem de gelişmiş ülkeler için başlamıştır. 1945-1973 yılları arasında altın çağını yaşayan sosyal refah devletleri, 1973 yılında I. Petrol Krizi'nin etkisiyle sosyal devlet anlayışını sorgulamaya başlamışlardır. Bu ülkelerin kamu ve özel sektör ekonomileri daralmış, iç ve dış borçları artmış ve neoliberal politikaları savunan ülkeler karşısında adeta onlar zayıf kalmışlardı. Haliyle ülkelerin sosyal devlet bakış açısını yavaş yavaş terk etmesi, neoliberal politikaların etkinlik kazanmasına zemin hazırlamıştır. Bu bağlamda, Türkiye' de yaşanan siyasal ve yönetsel dönüşümleri sermaye birikimi süreçlerinden ve neoliberal sosyal politika eğilimlerinden kopuk olarak ele aldığımız sürece, bir bütün olarak devletin geçirdiği yapısal dönüşümleri göz ardı etme riski taşırız (Oğuz, 2012).

\footnotetext{
${ }^{1}$ Arş. Gör. Hacettepe Üniversitesi IiBF, Sosyal Hizmet Bölümü. erkulercem@gmail.com, Yazar ORCID bilgisi: https://orcid.org/0000-0001-9453-8319.

2 Dr. Öğr. Üyesi, Manisa Celal Bayar Üniversitesi SBF, Sosyal Hizmet Bölümü. bugrayildirim58@gmail.com, Yazar ORCID bilgisi: https://orcid.org/0000-0002-2840-3624.
} 
Neoliberal politikalar, 1973-1980 dönemlerinde etkin olmasının yanı sıra, 1980li yılların başında Türkiye'deki askeri ve siyasi dönüşümle beraber, güçlü etkisini daha fazla bir şekilde hissettirmeye başlamıştır (Erkul ve Demir-Erkul, 2019). Bu dönemde temel amaç, devletin küçültülmesi söylemiyle bir önceki dönemin kurumlarının ortadan kaldırılması ve neoliberal politikaların hızla ve siyasi aktörlerin direnci olmaksızın uygulanmaya başlaması olmuştur. Söz konusu amacı gerçekleştirmeye yönelik kullanılan temel mekanizma ise, iktidarın siyasal partilerden devlet aygıtına, devlet aygıtından da yeni oluşturulan bir ekonomi bürokrasisine aktarılması olmuştur (Oğuz, 2012). Dolayısıyla yeni ekonomik bürokrasiyi şekillendiren neoliberal politikalar, hem gelişmekte olan ülkeleri hem de Sovyet Sosyalist Cumhuriyetler Birliği'nin (SSCB) yıkılmasıyla ortaya çıkan Doğu Avrupa ülkelerini etkisi altına almıştır. Dahası neoliberal politikaya sahip ülkeler kendi güdümündeki Uluslararası Para Fonu (IMF) ve Dünya Bankası (WB) aracılığıyla diğer ülkelerin iç ekonomilerini yönlendirmeye başlamıştır. Neoliberal politikaya sahip ülkeler tarafından diğer ülkelerin iç ekonomilerini yönlendirme eğilimi kimi zaman diğer ülkeler adına olumsuz yönde etkiler doğurmuştur. Söz konusu olumsuz etkilerin ilk yansıtıldığı harcama kalemleri ise diğer ülkelerin sağlık ile sosyal harcamaları olmuştur.

Öte yandan Erdem (2010), 1980 ile başlayan dönemin Türkiye'de neoliberal politikalar ve özellikle ödemeler dengesinin sermaye hesabının serbestleştirilmesi ile anılan süreç olarak tanımlandığını belirtmiştir. Beklendiği gibi dışa açık ekonomik büyümeyi gerçekleştirmek yerine ekonominin dış şoklara karşı kırılgan bir yapıya dönüştürüldüğünü, 1994 ve 2000/2001 yıllarında Türkiye'de yaşanan finansal krizlerin, ağır bir dış borç yükü ile ülkeyi karşı karşıya bıraktığını vurgulamıştır (Erdem, 2010). Büyük ölçüde sıcak para girişlerine bağlı olarak artan dış borçlar ciddi bir tehdit haline dönüşürken, doğrudan yabancı sermaye girişleri olarak sınıflandırılan birleşme ve ele geçirmeler/edinimler ile mülklerin ve ekonomik varlıkların el değiştirme sürecinin de hızlandığı anlaşılmıştır (Erdem, 2010). Türkiye'de neoliberal politikalar ve sermaye arasındaki ilişki bu minvalde sürüp giderken neoliberal politikalar; sağlık ve sosyal alanlara da yayılmaya devam etmiştir.

Örneğin 1990'lı yıllarda başlayan ve 2000 yılı sonrası hız kazanan sağlık hizmetlerinde yeniden yapılanma çalışmaları ile sağlık hizmetlerinin örgütlenmesi, finansmanı ve sunumunda neoliberal politikalar ülkemizde köklü değişiklikler gerçekleştirmiştir. Özellikle nüfus artışı, demografik yapının değişmesi, halkın beklentileri ve teknolojik gelişmeler sağlık harcamalarında artışa yol açmış, bunun karşısında devletler yeniden yapılanma arayışları ile maliyetleri kontrol etme çabasına girmiştir (Erol ve Özdemir, 2014). Ayrıca son yirmi yılda tüm dünyada olduğu gibi Türkiye'de de refah devleti kazanımlarının (eğitim, sağlık ve sosyal güvenlik hizmetleri) krize girdiği görülmektedir. Söz konusu kazanımlar içinde bilhassa Türk sağlık sistemi adına temel yasal düzenleme ve resmi belgelerin incelenmesiyle reform çabalarının nihai hedefi; merkezi olarak yönetilen sağlık hizmeti sunumunun dönüştürülmesi ve kolaylıkla sağlık hizmetlerinin piyasa ekonomisi işleyişine tabi kılınmasıdır (Erençin ve Yolcu, 2008; Yıldız, 2008). Unutulmamalıdır ki sağlık özel örneği üzerinden vurgulanan sisteminin piyasa ekonomisine tabi kılınması eğitim, sosyal güvenlik gibi sosyal alanlarda yapılan diğer harcamalara da sıçrayabilir. Böylece neoliberal politikalar devletin politika alanlarında nüfuzunu hissedilir şekilde yükseltmeye devam edebilir.

Türkiye'de sosyal politikaların ve sosyal hizmetlerin şekillenmesinde neoliberal politikaların önemli bir rolü bulunmaktadır. Koray (2012: 124-125)'a göre 29 Ekim 1923 tarihinde kurulan Türkiye Cumhuriyeti'nin ilk başlarda izlediği devletçilik politikası; dezavantajlı grupları çok fazla kapsayıcı olmayan yasalarla korumakta, daha sonrasında ise Türkiye'nin sosyal devlet kavramını içselleştirilmesi ile birlikte ilerici ve çağdaş yasalarla kapsayıcılığını hem genişletmekte, hem de 
modernleştirmektir. Bu bağlamda, sosyal politika ve sosyal hizmet alanında, 1961 ve 1982 Anayasası ile birlikte devletin sosyal niteliğinde önemli ve radikal değişimler yaşanmıştır. Tecrübe edilen bu önemli radikal değişimlerin temel nedeni ise her iki anayasa da sosyal devlet ilkesinin yer almasıdır.

Diğer taraftan Koray (2012: 131), 1961 Anayasası'nda sosyal hukuk devleti ve sosyal adalet kavramlarının bulunmasının, sosyal politikada büyük bir dönüşüme etkisinin olduğunu vurgulamıştır. Ek olarak, Koray (2012: 133-134), Türkiye Cumhuriyeti'nin 1982 Anayasa'nın 1961 Anayasası'nı kısıtladığını da özellikle belirtmiş, 1982 Anayasası'nın 2.Maddesinde yazan sosyal bir hukuk devleti kavramının, uygulama alanına geçildiğinde sözde olduğunu da ifade etmiştir. AsIında burada üzerinde durulması gereken nokta, 1945-1973 yılları arasında Altın Çağı'nı yaşayan refah devlet anlayışının, 80'li yılların başından itibaren rekabet ve sermayenin küreselleşmesiyle birlikte sosyal devleti haliyle sosyal hukuk devletini yerinden etmesidir (Kazgan, 2013: 129).

1980'li yılları Buğra (2015: 198-199), özellikle sosyal devlet anlayışının yoğun bir şekilde eleştirildiği ve toplumun neoliberal politikaların bir ayağı olan serbest piyasayla hizaya getirilmeye çalışııı̆ı̆ bir dönem olarak adlandırmaktadır. Öyle ki bu dönemin bölüşüm dinamikleri, Türkiye'de imece usulü şeklinde tanımlanan sosyal koruma sistemini de etkilemeye başlamıştır. İmece usulü sosyal koruma sisteminden kasıt ise bir bakıma sosyal güvencesi olmayan bireylerin sosyal korumaya/bakıma diğer vatandaşlar üzerinden katılmasıdır. Sosyal koruma/bakım sadece yoksul tabakayı değil aynı zamanda ihmal ve istismar tehlikesi altında bulunan çocukları, yaşıları, öğrenme güçlüğü çekenleri, engellileri vb. dezavantajlı grupların tamamını kapsamaktadır (Alcock vd., 2011: 462). Bu kapsamda, 1986 yılında Sosyal Yardımlaşma ve Dayanışma Fonu ve 1992 yılında resmi olarak sağlık güvencesi olmayan yoksulların sağlık hizmetlerine erişebilmesini sağlayan Yeşil Kart uygulaması yürürlüğe konulmuştur. Tüm bu gelişmeler ışığında, neoliberal ekonominin toplumda yaratacağı olası olumsuz etkilerini azaltmak için Türkiye'nin bu önlemleri aldığı söylenebilir.

Özetle bir toplumdaki sağlık ve sosyal sistem özelliklerinin ülkenin hatta dünyanın içinde bulunduğu siyasi atmosferle çok yakından ilişkisi olduğu pek çok kez gösterilmiştir. Kapitalizmin tarihi ile başlayan örgütlü sağlık hizmetlerinin ya da sosyal politika harcamalarının zaman içindeki değişimi ve dönüşümü de kapitalizmin geçirdiği aşamalar ile paralellik göstermektedir. İçinde bulunduğumuz neoliberal dönemde yeniden şekillenen sağlık hizmetleri, piyasa dinamiklerinin etkisi altına girerek ticarileşmiş (Etiler, 2011), diğer sosyal politika alanlarında da benzer riskler söz konusu olmuştur. Yukarıda verilen açıklamalar doğrultusunda neoliberal politikalardan etkilenen ülkelerden birinin Türkiye olduğu da açıktır. Bu bağlamda, neoliberal politikaların gün yüzüne çıktığı 1980 yılı, Türkiye'ye ilişkin sağlık ve sosyal harcamaların değerlendirilmesinde başlangıç yılı seçilmiştir.

Ayrıca sağlık ve sosyal harcamalara ilişkin verileri ülkeler arasında karşılaştırma yapabilmek için uluslararası bir kuruluşun veri tabanından yararlanmakta fayda görülmektedir. Sağıık harcamalarını ilişkin veriler için, OECD veri tabanından Sağlık Hesapları Sistemi (SHA) kullanılmıştır. OECD (2017)'nin raporuna göre Sağlık Hesapları Sistemi; OECD, Eurostat (Avrupa İstatistiki Veri Tabanı) ve WHO (Dünya Sağlık Örgütü) tarafından sağlık harcamalarına ilişkin ortak veri toplama tabanı olarak geliştirilmiştir.

Sosyal harcamaları ilişkin veriler için ise, OECD veri tabanı ya da başka bir ifadeyle Sosyal Harcama Veritabanı (Social Expenditure Database-SOCX) kullanılmıştır. Kaldı ki ülkelere yönelik sosyal harcamaları incelediğimizde OECD’nin kullandığı ifadeyle Sosyal Harcama Veritabanı (SOCX) ile Eurostat'ın kullandığı Avrupa Bütünleştirilmiş Sosyal Koruma İstatistikleri Sistemi 
(ESSPROS) olmak üzere iki eğilim karşımıza çıkmaktadır. SOCX; yaşılık, dul ve yetim, sağlık, aile, işsizlik, konut, iş göremezlik kapasitesi, aktif iş gücü programları ve diğer yardımları kapsarken (OECD, 2019), ESSPROS ise yaşlılık, dul ve yetim, sağlık, aile, işsizlik, konut, özürlülük ve sosyal dışlanma yardımlarını kapsamaktadır (Eurostat, 2016). Türkiye ise sosyal koruma, harcama ve gelirlerine ilişkin verileri ise ESSPROS el kitabına göre oluşturmuştur (TÜiK, 2019). Son tahlilde, SOC ve ESSPROS tarafından kullanılan sosyal harcama tanımları birbiriyle büyük oranda uyumludur, ancak kapsam ve organizasyonda farklılıklar vardır. Bu sosyal harcamalara ilişkin tanımlamalarda SOCX ile ESSPROS arasındaki farklar şunlardır (Feddersen, 2015):

- ESSPROS, sosyal harcamaların finansmanı hakkında bilgi içerdiğinden, SOCX ile karşılaştırıldığında, ESSPROS daha geniş kapsamlıdır.

- Bireylere verilecek desteğe odaklanıldığında ise ESSPROS'un kapsamı, SOCX'a göre daha geniştir ve bu bağlamda ESSPROS'da bulunan sosyal harcamalar, kamu sağlık harcamalarını (sağlık eğitimleri, tıbbi tesislere yapılan yatırım harcamaları) içermemektedir.

- Aktif işgücü piyasa programlarının, ESSPROS'da bir işlevi bulunmamaktadır. Aktif işgücü piyasası programlarının bazı harcamaları ESSPROS'da işsizlik altında rapor edilmektedir, ancak bu tanım SOCX'a göre daha dardır. Örneğin, daha önce işsiz kişilerin istihdam maliyetine yönelik devlet sübvansiyonları ESSPROS'a dahil edilmemiştir.

- 0-5 yaş arası çocuklar için çocuk bakımı ve okul öncesi eğitim SOCX'da aile kalemi kapsamında yer bulur. Ancak ESSPROS'da çocuk bakımı ve okul öncesi eğitim, yaşa bakılmaksızın aile kapsamındadır. Örneğin bazı ülkelerde çocuklar, 5,6 ve 7 yaşında okula başlayabilmektedir. Çocuk okula başlar başlamaz, SOCX, bu çocuklara sosyal harcamayı keserken, ESSPROS bu harcamaları kesmemektedir.

- Son olarak, sosyal harcamalar SOCX eğiliminde idari giderleri kapsamazken, ESSPROS eğiliminde kapsamaktadır.

Illaveten çalışmada sağlık ve sosyal harcamaların seçilmesinin nedeni ise sosyal hizmet bakış açısının OECD verileri kullanılarak yapılacak olan değerlendirmeye yansıtılmak istenmesidir. Bu durumda sosyal hizmetin devlet iktidarını bireylere, ailelere, gruplara ve topluluklara tercüme etmek ile yükümlü bir ara alan kapladığını söylemek yanlış olmayacaktır (Pollack, 2010). Dahası bu çalışmada OECD istatistiklerini kullanma yoluna gidilmesi; sosyal hizmetin toplumun bileşenlerine yönelik tercüme etme işlevini yerine getirebilmesi için neoliberal analizler tarafından sunulan pratik anlayışları sağlık ve sosyal harcamalar ekseninde tarafsız bir şekilde görünür kılmak istemesindendir. Özellikle neoliberal yöntemin temel özelliklerinden biri olan kısıtlanan harcama odakları OECD verileri ile açıkça ortaya konulmaya çalışılmıştır. Son olarak, OECD verilerinin kullanılmasının bir başka nedeni ise, Türkiye'yi sadece Avrupa Birliği grubu içinde değerlendirmeyip, daha farklı ülke gruplarıyla karşılaştırmak titizliğimizdendir. Dolayısıyla bu çalışmanın amacı Türkiye'nin sağılık ve sosyal harcamalarının sosyal hizmet bakış açısı temelinde OECD verileri kullanılarak retrospektif karşılaştırmalı bir şekilde incelenmesidir. Bu bağlamda metin öncelikle sosyal hizmetin neoliberal politikalara sunabileceği katkıyı ele alacak sonrasında ise Türkiye ve OECD ülkelerine ilişkin sağıık ve sosyal harcama istatistiklerinin analizini yapacaktır. Son tahlilde çalışmanın ana amacına bağlı olarak alt amaçları ise aşağıdaki gibi sıralanmıştır:

1. 1980-2013/2015 Dönemine ilişkin OECD ülkelerini içeren tanıtıcı bulgular nelerdir?

2. Sağlık harcamalarının Gayri Safi Yurtiçi Hasıla (GSYiH) içindeki değişim oranı OECD ülkeleri arasında nasıldır? 
3. Kişi başına düşen sağlık harcama miktarının OECD ülkeleri arasında değişim oranı nasıldir?

4. Sosyal harcamalarının GSYiH içindeki değişim oranı OECD ülkeleri arasında nasıldır?

5. Kişi başına düşen sosyal harcama miktarının OECD ülkeleri arasında değişim oranı nasıldır?

\section{Sosyal Hizmet Neoliberal Politikaları Etkileyebilir mi?}

Küresel ekonomik koşulların sosyal harcamalar üzerindeki baskısı ve gittikçe değişen sosyal güvenlik gelirleri hükümetlerin bu talepleri karşılamasını zorlaştırmıştır. Tüm bunlara bir de sağlık hizmetlerinin gittikçe artan maliyetleri eklendiğinde hükümetlerin baş etmeleri gereken kriz senaryosu tüm açıklığıyla ortaya çıkacaktır. Böylesi bir kriz tarifi; devletin artan talebe yanıt verebilmek için vergileri artırmak, prim toplama sistemini gözden geçirmek ya da doğrudan bütçeden karşılamak gibi yöntemlere başvurma olasılığında yeterli çözümlere sahip olmayacaktır. Değişen küresel ekonomik ortam ve liberalleşme süreçleri öne sürülerek devletin artan maliyetlere karşı harcamaları kısması ya da hizmetleri özelleştirmesi dışında tüm seçenekler peşinen elenecektir (Ağartan, 2007).

Geriye kalan seçeneklere sosyal hizmet bakış açısı ile yaklaşırken bir takım hatırlatmalarda bulunmak ise yararlı olacaktır. Öncelikle politika yaparken ve uygularken ana etik değerlere daha doğrusu hak, adalet ve yarar ilkelerine sadık kalmak gerekir (Yamatani ve Feit, 2013) çünkü insanların onurlu bir şekilde yaşaması ve sosyal haklara sahip olması neoliberal politikalara rağmen sosyal devlet ile yakından ilişkilidir (Erkul ve Demir-Erkul, 2016). Ilaveten hizmet sunumu ve yapısı değişirken; değişmemesi gereken tek şey hem hizmetleri sunanlar hem de hizmetlerden yararlananlar açısından insan onur ve haysiyetine saygı duyulması ve hizmetlerin sosyal adalet anlayışına uygun bir çerçeve çizilerek dağıtılmasıdır (Yıldırım, 2016). Bu noktada sosyal hizmet neoliberal politikaları etkileyebilir çünkü sağlık ve sosyal harcamaların hak temelli sunum ölçütlerini denetleyebilir. Nitekim Ferguson ve Lavalette (2006) sosyal hizmetin insanların hayatlarını iyileştirebileceğini; onların acısını, sıkıntısını ve sorunlarını anlamalarına ve bunlarla baş etmelerine yardımcı olabileceğini; damgalanmaya ve ayrımcılığa karşı meydan okuyabileceğini ve sosyal adalet mücadelesinin politik bağlamda bir parçası olabileceğini açıklar. Ayrıca sağlık ve sosyal harcama kalemlerinin sosyal hizmet bakış açısıyla irdelenmesi hükümetlere yardımcı olabileceği gibi gelecekteki farklı politika üretimlerine de ışık tutabilir, farkındalık yaratabilir.

ikinci olarak; pek çok sosyal hizmet araştırmacısının tıbbi refah, çocukların korunması, kadınların ihtiyaçları gibi birbirinden farklı alanlara odaklandığını ancak çok az sayıdaki kritik sosyal hizmet araştırmacısının düzenleyici politika ve stratejilerin nasıl ortaklaşa sunulması gerektiği hakkında düşündüğünü ifade edebiliriz (Pollack, 2010). Sağlık ve sosyal harcama eşitsizliklerine tepki vermede sosyal hizmetin önemli bir rolü vardır ve bu rol, hem ulusal hem de uluslararası düzeyde uygulama modelleri, politika geliştirme, lobicilik, savunuculuk ve politika temelli harcamaların değerlendirilmesini kapsar (Alston, 2007). Toplumun gelişimi ve sunulan hizmetlerden bütün bireylerin yararlanması için sosyal hizmet açık bir yol gösterecektir çünkü heterojen bir politika sunumunda devletin düzenleme stratejilerinin güncellenmesi, refah devleti, özel sektör ve sivil toplum kuruluşları arasında işbirliği ortamının geliştirilmesi yine sosyal hizmetin adımları ile şekillenir. Neoliberal politikalara teslim olmaksızın toplum odaklı alternatif uygulamaların sunulması adına firsatlar sunar. 
Son olarak politika yapıcılar, profesyoneller ve vatandaşlar, yalnızca sosyal sorunları değil, aynı zamanda rahatsız edici veya riskli olan sosyal politikaları da tanımlamak ve yönetmekle giderek daha fazla ilgilenmektedir. Bu konuda sosyal hizmette nispeten sessiz kalmayarak başkasının sorunu haline gelen sağlık ve sosyal harcamaların irdelenmesini kendi bakış açısıyla gerçekleştirmeye çalışmaktadır çünkü sosyal hizmetin bireyler ile topluma aracılık etme konusunda uzun süredir devam eden bir taahhüdü bulunur (Sharland, 2006). Toplum yararına verilmiş olan bu taahhüt sosyal hizmetin tanınması, anlaşılması ve insan odaklı bakış açısının kavranması adına birtakım riskler taşısa da sosyal hizmet ile risk yoğun olarak ilişkilendirilmiştir ve çağdaş sosyal hizmet, risk paradigmasından önemli ölçüde etkilenmiştir (Kemshall, 2010). Bununla birlikte, sosyal hizmette risk kavramı, sosyal politikaların etkilediği kişiler ile biçimlenebilmektedir. Hangi hizmetlerden, hangi nüfus gruplarının, nasıl yararlandığının kavranabilmesinin yanı sıra harcamaların nasıl ve hangi alanlara yönelik yapıldığının da ortaya konması sosyal risklerin politik yapısını gözler önüne sermek için yararlı olacaktır. Politika ve uygulamalarda risk rasyonalitesini açıklamak aslında sosyal engellerin çözümünü de beraberinde getirecektir. Öyleyse geçmişe yönelik sağlık ve sosyal harcama istatistiklerini değerlendirirken sosyal hizmetin risk olarak algılayacağı noktaları paylaşmak ve modernleşme programlarının göstergelerini tartışmak gerekecektir.

\section{Modernleşme Programları: Sağlık ve Sosyal Harcamalar}

Modernleşme programları, hizmet alanları istedikleri hizmetleri seçmeyi ve ulaşmayı deneyimleyebilecek tüketicilere çevirerek desteklemeyi önerir. Hizmet alanların kamu hizmetlerine ortak üretici olarak dâhil olması, yeniliklerin fonlanmasındaki verili kaynakların kısıtlılığı düşünülerek, yapmacık olmaktan daha fazlasını, hizmetlerin elde edilebilirliğinin artmasını ve hizmet alanların bu hizmetler için harcanan zaman boyunca ödeme yapmasını sağlamıştır. Aslında buradaki amaç, hizmet alanlara doğrudan ödemenin yapılmasının ve bireysel bütçenin kendi kontrollerinde olduğu birey merkezli uygulamaya geçişin istenmesidir (Adams vd., 2014: 51). Bu durum her ne kadar kişi başına düşen sağlık ve sosyal harcama miktarını artıracak gibi görünse de, zaman içerisinde bireylerin bu kaynaktan yararlanması etkin ve verimli olacaktır. Bir bakıma devlet ve özele yönelik sağlık ile sosyal harcamaların, sadece kurumlar tarafından değil hizmet alanların da içerisinde olacağı ortaklaşa bir mekanizmayla bu harcamaların planlanması söz konusu olabilir. Örneğin, kamu kuruluşları tarafından aileye engelli maaşı verilmektedir. Ancak söz konusu bu uygulama, tek taraflı bir yardım anlayışına ve hiyerarşik bir durumun ortaya çıkmasına sebebiyet verebilir. Doğru olan hamle ise sosyal hizmet uzmanı ve hizmet alanların daha eşit olduğu bir sisteme geçiş için zemin hazırlanmasıdır (Mullaly, 1997; Hugman, 2003).

Öte yandan neoliberal politika çerçevesinde sosyal hizmetler alanı; mekanikleşmeye, bürokratlaşmaya ve masa başı işlerin artmasına doğru bir kayma yaşamıştır. Jones (2001: 552), kamuda sosyal hizmet uzmanı olduktan sonra daha fazla ofiste vakit geçirildiğini, dışarda sahada olunması gerekirken çok fazla formlarla uğraşıldığını ve bu nedenle de müracaatçılarla doğrudan iletişim kurmanın zorlaştığını ifade etmektedir. Böylelikle küresel ekonomi, demografik değişim ve neoliberalizmin yükselişi kamu sektörü içinde yer alan sosyal hizmet kuruluşlarının yeni yönetim ahlakına katkıda bulunmaktadır (Harlow, 2003). Durum böyle iken sosyal hizmet uzmanları görevlerini alternatif kariyer fırsatları için terk etmektedir ve kamuda nitelikli sosyal hizmet uzmanı sıkıntısı oluşmaktadır (Harlow, 2004). Türkiye'de sosyal hizmet sunumunda yeni yönetim anlayışı nitelikten çok niceliğe önem verirken nitelikli personeli elde tutma konusunda yaşanan zorluklar göz ardı edilmektedir. Nitekim yeni yönetim anlayışı bazen kamu sektöründe 
yer alan sosyal hizmet kuruluşlarının sosyal uygulamalarını zayıflatabilmektedir (Kirkpatrick ve Ackroyd, 2003).

Oysa İngiltere ve başka ülkelerde, sosyal hizmetlerde yeni bir yönetim rejimi kurma girişimleri; mevcut profesyonel sosyal hizmet örgütlenme biçimlerinin verimsiz olarak değerlendirilmesi, bu örgütlerin kendi kendine hizmet veremediğinin anlaşılması ve hizmet alanların ihtiyaçlarını karşılayamaması nedeniyle denenmekteydi (Kirkpatrick, 2006). Neoliberal ülkelerdeki yeni yönetim anlayışı Türkiye'deki gibi sosyal hizmet uygulamasında sayısal üstünlüğü koruma ya da arttırma kaygısı taşımıyordu. Neoliberal ülkelerde bilhassa sosyal harcamalar ile sosyal hizmetlerin planlanması ve sunumu arasındaki ilişki doğrusal ve ihtiyaç odaklıydı. Sosyal sorunları çözmek ayrı bir hedefti ancak sosyal sorunların ortaya çıkmasını engelleyecek koruyucu önleyici tedbirlerin zeminini hazırlamaya yönelik sosyal harcamalar öncelikliydi. Doğal olarak sosyal hizmet uzmanları bu mantalitede etkin birer profesyoneldi.

Rogowski (2011)'ye göre sosyal hizmet uzmanlarının günümüzdeki uygulamaları, yöneticiler tarafından belirlenmekte ve sıkı bir şekilde kontrol edilmektedir. Bu durumda neoliberal ideolojiyi kabul eden ülkeler; piyasanın devletten üstün olduğunu ve kamu hizmetlerinin özel sektör gibi yönetilmesi gerektiğini savunur. Sosyal hizmet uzmanları artık sosyal demokratik refah devletinin idari sistemlerinde çalışamamaktadır ve yöneticilerin artan gücü, sosyal hizmet mesleğinin geliştiği sistemi baltalamaktadır (Rogowski, 2011).

Tüm bunları ele aldığımızda, postmodernizm ve neoliberal politikaların etkisiyle sosyal hizmette bilginin dönüşümü yaşanmaktadır. Postmodern yaklaşımın sosyal hizmette bilginin dönüşümüne olumlu etkisi; mesleki bilginin geçici bir doğası olduğunu ve sosyal hizmet müdahalesinin iyi yaşam ve akış sürecinin çoğulcu bir yapıya dönüşmesini ifade edilebilir (Parton, 1994; Hugman, 2003). Aslında bir bakıma küreselleşmeyle birlikte, bilgiye ulaşmada kolaylıklar sağlanırken bir bakıma da büyük bir bilgi havuzu içinden doğru bilgiyi kullanma sıkıntısı yaşanmaktadır. Bu aşamada, kamunun ya da özel örgütlerin sağlık ve sosyal harcamalarını ve hizmetlerini yönlendirirken doğru ve hızı bir şekilde hizmet alıcısına ulaştırması beklenmektedir. Buna ek olarak, harcamalar ve hizmetlerin, hizmet kullanıcısı ile birlikte devletin veya özel kuruluşun karar vermesi, planlanması ve son hadde hizmet kullanıcısının tasarrufuna bırakılması önerilebilir. Böylelikle hizmet kullanıcısının güçlenmesi sağlanabilir.

\section{Yöntem}

Çalışmanın metodolojik eğilimi nicel yöntemde ikincil verilerin analiz tekniğine dayalı tepkisiz araştırmadır. Tepkisiz araştırmada kullanılan veriler ya da incelenenler bir araştırma projesinin parçası olduğunu bilmezler ve tepkisiz araştırma teknikleri yorumlayıcı ya da eleştirel araştırmacılar tarafından kullanır (Neuman, 2012: 462-463). Bu çalışmada sağlık ve sosyal harcama ekseninde ele alınan OECD ülkeleri ile Türkiye araştırmanın inceleme kapsamındadır ve araştırmacılar tarafından sağlık ile sosyal alanda yapılan harcamalar araştırma amaçları doğrultusunda yorumlanmıştır. Ülkeler genel verilerini OECD sistemine gönderdiği ve verilerini paylaşmak amacıyla söz konusu sistem ile işbirliği yaptıkları için bu çalışmada incelemeye tabi tutulacaklarını haber vermek yersiz olacaktı. İlaveten, tepkisiz araştırmanın dört önemli tekniğinden biri ise ikincil verilerin analizidir. Ikincil veri analizi araştırmacılar için zengin içerikli çalışmalar yapma olanağı sağlar. Var olan istatistiklerin özel bir durumudur. Daha önce başkaları ya da büyük ölçekli kurumlar, oluşumlar tarafından toplanan verilerin yeniden değerlendirilmesidir. Özellikle uluslararası karşılaştırmaların konu edildiği araştırmalarda kullanır ve karşılaştırma yapmaya olanak tanır (Neuman, 2012: 482). 
Çalışmanın ikincil verileri OECD'den çekilmiştir. OECD ülkelerinin sağlık ve sosyal harcamaları sistemden zengin içerikli değerlendirme yapabilmek adına tek tek taranmıştır.

Tek tek taranan OECD ülke verileri bir bütün içine yerleştirilmiş ve elde edilen tüm veriler birleştirilmiştir. İkincil veriler aşağıda belirtilmiştir:

- 1980-2015 Dönemini İçeren OECD Ülkelerini ilişkin Toplam Sağlık Harcamalarının GSYiH İçindeki Payı,

- 1980-2013 Dönemini İçeren OECD Ülkelerine Illişkin Toplam Sosyal Harcamalarının GSYiH İçindeki Payı,

- 1980-2015 Dönemini İçeren OECD Ülkelerine İlişkin Kişi Başına Düşen Sağlık Harcaması (Cari Fiyat ve Cari Satın Alma Gücü Paritesi, Amerikan Doları Cinsinden),

- 1980-2013 Dönemini İçeren OECD Ülkelerine İlişkin Kişi Başına Düşen Sosyal Harcama (Cari Fiyat ve Cari Satın Alma Gücü Paritesi, Amerikan Doları Cinsinden)'dır.

En son safhada Türkiye ve OECD ülkeleri için sağlık ve sosyal harcama istatistikleri, ikincil verilerin oransal analizi ile değerlendirilmeye tabi tutulmuş ve karşılaştırılmıştır. Yapılan karşılaştırma aynı zamanda tüm OECD ülkelerindeki sağlık ve sosyal harcama göstergelerinin ölçümünü sistematik hale getiren bir veri setinin seçilmesini gerekli kılmıştır. Seçilen veri seti, benzer harcama ölçütlerine dayanarak farklı OECD ülkelerinde sağlık ve sosyal harcama istatistiklerinin standart şekilde karşılaştırılmasına imkân sağlar. Nitekim 1980-2013/2015 dönemi için Türkiye'nin sağlık ve sosyal harcama alanlarına yönelik elde edilen verilerin sosyal hizmet anlayışı, felsefesi, düşüncesi, hassasiyeti ve bakış açısı ile OECD ülkeleri ile karşılaştırılması, Türkiye'deki modernleşme programlarında hizmet alanlara yönelik yapılan harcamaların tarihini aydınlatmaya yönelik çabaları kolaylaştırabilir. Bu yönüyle çalışma Türk sosyal hizmet literatüründe ilk karşılaştırmalı retrospektif araştırma olması açısından da önemlidir.

\section{Sağlık ve Sosyal Harcama İstatistiklerini Tanıtıcı Bulgular}

Tablo 1, 1980-2015 dönemlerini içeren OECD ülkelerine ilişkin toplam sağlık harcamasının GSYIH içindeki payını göstermektedir. Yıllar itibariyle seçilmiş OECD ülkelerinin hepsi, toplam sağlık harcamasının GSYiH içindeki payını artırmıştır. 2015 yılı incelendiğinde, hemen hemen tüm OECD ülkelerinin (Amerika Birleşik Devletleri hariç) toplam sağlık harcamasındaki, kamu sağlık harcamasının payı, özel sağlık harcamasından daha yüksektir. Buna ek olarak, OECD ülkelerin özellikle de Anglosakson ülkelerin, özel sağlık harcamasının GSYiH içindeki payını yükselttiği gözlenmiştir. Son olarak, 1980 ve 2015 yılları incelendiğinde sosyal demokrat ülkelerin toplam sağlık harcaması içindeki özel sağlık harcaması payının az da olsa yükseldiğini ifade edebiliriz.

Tablo 1: 1980-2015 Dönemini Içeren OECD Ülkelerine iliş̧kin Toplam Sağlık Harcamanın GSYiH Içindeki Payı

\begin{tabular}{|c|c|c|c|c|c|c|c|c|c|c|c|c|c|c|c|}
\hline \multirow[t]{2}{*}{ Ülkeler/Yıllar } & Sağlığ & $\begin{array}{c}\text { Yöneli } \\
\text { Zoru } \\
\text { nu Kes }\end{array}$ & $\begin{array}{l}\text { Hüküm } \\
\text { ve } \\
\text { u Katkı } \\
\text { ninin H }\end{array}$ & $\begin{array}{l}\text { t Progr } \\
\text { Paylı } \\
\text { rcamal }\end{array}$ & mları & Özel & $\begin{array}{r}\text { Sağ } \\
\text { Kesimir }\end{array}$ & $\begin{array}{l}\text { ığa Yör } \\
\text { Yaptığ }\end{array}$ & $\begin{array}{l}\text { elik } \\
\text { Harca }\end{array}$ & alar & \multicolumn{5}{|c|}{$\begin{array}{l}\text { Sağlığa Yönelik } \\
\text { Toplam Harcamalar }\end{array}$} \\
\hline & 1980 & 1990 & 2000 & 2010 & 2015 & 1980 & 1990 & 2000 & 2010 & 2015 & 1980 & 1990 & 2000 & 2010 & 2015 \\
\hline AUS & 3.67 & 4.29 & 5.21 & 5.81 & 6.18 & 2.16 & 2.19 & 2.41 & 2.66 & 3.08 & 5.83 & 6.47 & 7.61 & 8.47 & 9.26 \\
\hline AUT & 4.73 & 5.75 & 6.97 & 7.70 & 7.88 & 2.31 & 1.98 & 2.26 & 2.41 & 2.47 & 7.04 & 7.74 & 9.22 & 10.11 & 10.36 \\
\hline BEL & m.d. & m.d. & 5.9 & 7.7 & 8.1 & m.d. & m.d. & m.d. & m.d. & m.d. & 6.15 & 7.11 & 7.94 & 9.94 & 10.36 \\
\hline CAN & 5.02 & 6.23 & 5.79 & 7.40 & 7.18 & 1.57 & 2.16 & 2.49 & 3.18 & 2.97 & 6.59 & 8.39 & 8.28 & 10.59 & 10.15 \\
\hline DNK & 7.37 & 6.63 & 6.74 & 8.83 & 8.91 & 1.08 & 1.42 & 1.37 & 1.61 & 1.68 & 8.45 & 8.05 & 8.10 & 10.45 & 10.59 \\
\hline FIN & 4.61 & 5.80 & 4.88 & 6.63 & 7.28 & 1.30 & 1.45 & 1.98 & 2.25 & 2.36 & 5.91 & 7.25 & 6.86 & 8.88 & 9.64 \\
\hline
\end{tabular}


Tablo 1: Devam

\begin{tabular}{|c|c|c|c|c|c|c|c|c|c|c|c|c|c|c|c|}
\hline Ülkeler/Yıllar & Sağlığ & $\begin{array}{c}\text { Yönelik } \\
\text { Zorun } \\
\text { nu Kesi }\end{array}$ & $\begin{array}{l}\text { Hüküm } \\
\text { ve } \\
\text { Katk } \\
\text { inin H }\end{array}$ & $\begin{array}{l}\text { ylı } \\
\text { amal }\end{array}$ & nları & Öz & Sa & 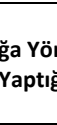 & ik & lar & \multicolumn{5}{|c|}{$\begin{array}{l}\text { Sağlığa Yönelik } \\
\text { Toplam Harcamalar }\end{array}$} \\
\hline FRA & 5.36 & 6.05 & 7.53 & 8.37 & 8.64 & 1.38 & 1.91 & 2.02 & 2.34 & 2.35 & 6.74 & 7.96 & 9.54 & 10.72 & 10.99 \\
\hline DEU & 6.30 & 6.06 & 7.81 & 9.21 & 9.42 & 1.79 & 1.97 & 2.00 & 1.79 & 1.66 & 8.10 & 8.03 & 9.81 & 11.00 & 11.08 \\
\hline IRL & 6.06 & 4.10 & 4.58 & 8.08 & 6.50 & 1.44 & 1.50 & 1.33 & 2.53 & 2.89 & 7.50 & 5.61 & 5.91 & 10.60 & 9.39 \\
\hline ITA & m.d. & 5.70 & 5.50 & 7.02 & 6.73 & 1.0 & 1.3 & 2.1 & 1.9 & 2.3 & m.d. & 7.0 & 7.58 & 8.95 & 8.99 \\
\hline JPN & 4.53 & 4.51 & 5.94 & 7.78 & 9.52 & 1.82 & 1.30 & 1.45 & 1.72 & 1.69 & 6.35 & 5.81 & 7.39 & 9.49 & 11.21 \\
\hline KOREA-NS & 0.70 & 1.48 & 2.16 & 3.79 & 4.01 & 2.78 & 2.20 & 1.84 & 2.62 & 3.20 & 3.48 & 3.68 & 4.00 & 6.41 & 7.21 \\
\hline NLD & 4.83 & 5.04 & 4.68 & 9.08 & 8.69 & 1.77 & 2.04 & 2.37 & 1.35 & 2.08 & 6.60 & 7.08 & 7.06 & 10.43 & 10.76 \\
\hline NZL & 5.05 & 5.50 & 5.83 & 7.78 & 7.50 & 0.69 & 1.17 & 1.64 & 1.88 & 1.91 & 5.74 & 6.67 & 7.47 & 9.66 & 9.41 \\
\hline NOR & 5.31 & 5.86 & 6.30 & 7.55 & 8.47 & 0.10 & 1.22 & 1.41 & 1.36 & 1.47 & 5.41 & 7.07 & 7.71 & 8.91 & 9.93 \\
\hline PRT & 2.99 & 3.58 & 5.90 & 6.85 & 5.85 & 1.80 & 1.94 & 2.47 & 2.97 & 3.01 & 4.79 & 5.52 & 8.37 & 9.82 & 8.86 \\
\hline ESP & 3.97 & 4.78 & 4.86 & 6.74 & 6.29 & 1.00 & 1.32 & 1.95 & 2.28 & 2.71 & 4.97 & 6.10 & 6.82 & 9.01 & 9.00 \\
\hline SWE & 7.21 & 5.77 & 6.34 & 6.95 & 9.27 & 0.63 & 1.48 & 1.07 & 1.54 & 1.81 & 7.84 & 7.26 & 7.41 & 8.49 & 11.07 \\
\hline CHE & m.d. & 3.8. & 5.2 & 6.7 & 7.7 & m.d. & m.d. & m.d. & m.d. & m.d. & 6.65 & 7.36 & 9.34 & 10.46 & 11.54 \\
\hline TUR & 0.71 & 1.50 & 2.92 & 4.16 & 4.04 & 1.85 & 1.01 & 1.81 & 1.17 & 1.19 & 2.42 & 2.51 & 4.73 & 5.34 & 5.23 \\
\hline GBR & 4.53 & 4.29 & 4.96 & 7.02 & 7.71 & 0.53 & 0.80 & 1.31 & 1.45 & 2.05 & 5.06 & 5.09 & 6.26 & 8.46 & 9.75 \\
\hline USA & 3.45 & 4.53 & 5.52 & 7.93 & 8.36 & 4.77 & 6.74 & 6.98 & 8.46 & 8.55 & 8.23 & 11.27 & 12.51 & 16.39 & 16.91 \\
\hline OECD & 4.55 & 4.87 & 5.52 & 7.23 & 7.47 & 1.59 & 1.86 & 2.11 & 2.37 & 2.57 & 6.18 & 6.77 & 7.72 & 9.66 & 10.08 \\
\hline
\end{tabular}

Kaynak: http://stats.oecd.org/ Erişim tarihi: 21.07.2017, m.d.: mevcut değil.

1980 ve 2015 yıllarını içeren Türkiye'ye ilişkin veriler incelendiğinde ise kamu sağlık harcamasının GSYiH içindeki payı 6.5 kat ve toplam sağlık harcaması oranı ise tam 2.16 kat yükselmiştir. Türkiye'nin 1982 Anayasası'na giren sosyal devlet ilkesi gereğince, devletin toplam sağlık harcamasındaki kamu payı \%20'den \%77'ye çıktığı ileri sürülebilir. Harcamalar artış eğilimi gösterse de Türkiye hala seçilmiş diğer OECD ülkelerine kıyasla toplam sağlık harcaması kalemine GSYiH içinden en az payı ayıran ülkedir. Dahası, Türkiye'ye ilişkin özel sağlık harcamasının GSYiH içindeki payı ise yıllar itibariyle düşüş göstermiştir.

Tablo 2: 1980-2015 Dönemini İçeren OECD Ülkelerine ilişskin Kişi Başına Düşen Sağlık Harcaması, Cari Fiyat ve Cari Satın Alma Gücü Paritesi, Amerikan Doları Cinsinden

\begin{tabular}{|c|c|c|c|c|c|c|c|c|c|c|c|c|c|c|c|}
\hline \multirow[t]{2}{*}{ Ülkeler/Yıllar } & \multicolumn{5}{|c|}{$\begin{array}{c}\text { Sağlığa Yönelik Hükümet Programları ve } \\
\text { Zorunlu Katkı Paylı } \\
\text { Kamu Kesiminin Harcamaları }\end{array}$} & \multicolumn{5}{|c|}{$\begin{array}{c}\text { Sağlığa Yönelik } \\
\text { Özel Kesimin Yaptığı Harcamalar }\end{array}$} & \multicolumn{5}{|c|}{$\begin{array}{l}\text { Sağlığa Yönelik } \\
\text { Toplam Harcamalar }\end{array}$} \\
\hline & 1980 & 1990 & 2000 & 2010 & 2015 & 1980 & 1990 & 2000 & 2010 & 2015 & 1980 & 1990 & 2000 & 2010 & 2015 \\
\hline AUS & 387 & 764 & 1475 & 2476 & 2950 & 228 & 390 & 682 & 1131 & 1471 & 616 & 1154 & 2157 & 3607 & 4420 \\
\hline AUT & 499 & 1122 & 2059 & 3226 & 3818 & 243 & 386 & 667 & 1011 & 1198 & 743 & 1508 & 2726 & 4236 & 5016 \\
\hline BEL & m.d. & m.d. & m.d. & m.d. & m.d. & m.d. & m.d. & m.d. & m.d. & m.d. & 645 & 1354 & 2246 & 3902 & 4611 \\
\hline CAN & 583 & 1257 & 1695 & 2966 & 3262 & 183 & 435 & 727 & 1276 & 1347 & 766 & 1692 & 2422 & 4242 & 4608 \\
\hline DNK & 751 & 1245 & 1991 & 3696 & 4160 & 110 & 266 & 405 & 675 & 783 & 861 & 1511 & 2396 & 4370 & 4943 \\
\hline FIN & 420 & 1038 & 1292 & 2541 & 3009 & 119 & 260 & 525 & 862 & 975 & 539 & 1298 & 1816 & 3403 & 3984 \\
\hline FRA & 517 & 1065 & 1960 & 3015 & 3464 & 133 & 337 & 525 & 844 & 943 & 650 & 1401 & 2484 & 3860 & 4407 \\
\hline DEU & 733 & 1299 & 2080 & 3650 & 4477 & 209 & 423 & 533 & 708 & 790 & 941 & 1722 & 2613 & 4359 & 5267 \\
\hline IRL & 389 & 549 & 1356 & 3493 & 3550 & 92 & 201 & 393 & 1092 & 1581 & 481 & 751 & 1749 & 4585 & 5131 \\
\hline ITA & m.d. & 1057 & 1487 & 2463 & 2509 & 96 & 243 & 560 & 676 & 842 & m.d. & 1301 & 2047 & 3140 & 3351 \\
\hline JPN & 388 & 866 & 1540 & 2626 & 3523 & 156 & 250 & 375 & 579 & 627 & 545 & 1117 & 1915 & 3205 & 4150 \\
\hline KOREA-NS & 17 & 122 & 391 & 1153 & 1384 & 67 & 182 & 333 & 798 & 1104 & 84 & 305 & 724 & 1951 & 2488 \\
\hline NLD & 511 & 948 & 1476 & 4066 & 4312 & 187 & 383 & 748 & 605 & 1030 & 698 & 1331 & 2225 & 4671 & 5343 \\
\hline NZL & 424 & 802 & 1254 & 2434 & 2862 & 58 & 171 & 353 & 587 & 728 & 482 & 973 & 1607 & 3020 & 3590 \\
\hline NOR & 519 & 1069 & 2317 & 4438 & 5598 & 10 & 222 & 520 & 800 & 969 & 529 & 1291 & 2836 & 5240 & 6567 \\
\hline PRT & 165 & 400 & 1053 & 1846 & 1737 & 99 & 216 & 441 & 800 & 894 & 264 & 617 & 1495 & 2646 & 2631 \\
\hline ESP & 281 & 655 & 1064 & 2181 & 2204 & 70 & 181 & 427 & 737 & 949 & 351 & 835 & 1491 & 2918 & 3153 \\
\hline SWE & 797 & 1159 & 1863 & 2902 & 4375 & 69 & 298 & 315 & 642 & 852 & 867 & 1457 & 2178 & 3544 & 5228 \\
\hline CHE & m.d. & m.d. & m.d. & m.d. & m.d. & m.d. & m.d. & m.d. & m.d. & m.d. & 1008 & 1968 & 3222 & 5371 & 6935 \\
\hline TUR & 20 & 86 & 261 & 665 & 821 & 53 & 58 & 162 & 188 & 242 & 69 & 144 & 424 & 853 & 1064 \\
\hline GBR & 400 & 749 & 1360 & 2517 & 3163 & 47 & 139 & 359 & 519 & 840 & 447 & 888 & 1719 & 3036 & 4003 \\
\hline USA & 435 & 1085 & 2014 & 3837 & 4672 & 601 & 1615 & 2545 & 4092 & 4779 & 1036 & 2700 & 4559 & 7929 & 9451 \\
\hline
\end{tabular}

Kaynak: http://stats.oecd.org/ Erişim tarihi: 21.07.2017, m.d.: mevcut değil, 
Tablo 2' de ise, 1980-2015 dönemini içeren OECD ülkelerine ilişkin Amerikan Doları cinsinden kişi başına düşen toplam sağlık harcamalarının miktarı gösterilmektedir. Yıllar itibariyle seçilmiş OECD ülkelerinin hepsi, kişi başına düşen toplam sağlık harcama miktarını yükseltmiştir. Anglosakson ülkelerin, kişi başına düşen toplam özel sağlık harcama miktarının, diğer OECD ülkelerine kıyasla yüksek olduğu söylenebilir. Buna ek olarak, 1980 ve 2015 yıllarını içeren Türkiye'ye ilişkin veriler incelendiğinde kişi başına düşen toplam kamu sağlık harcama miktarı 41 kat, kişi başına düşen özel sağlık harcama miktarı 4.5 kat ve toplam sağlık harcama miktarı ise tam 15.42 kat yükselmiştir.

Tablo 3, 1980-2013 dönemlerini içeren OECD ülkelerine ilişkin toplam sosyal harcamanın GSYiH içindeki payı ile özel ve kamu sosyal harcama payını göstermektedir. Yıllar itibariyle seçilmiş OECD ülkelerinin hemen hemen hepsinde (Hollanda hariç), kamu sosyal harcamasının GSYIH içindeki payı artmıştır. Dahası 1980 ve 2015 yıllarına ait Türkiye'ye ilişkin veriler incelendiğinde, toplam sosyal harcamanın GSYiH içindeki payı yaklaşık 3.3 kat yükseldiği görülebilir. Özel sosyal harcamanın GSYIH içindeki payının, Avusturya ve Danimarka hariç, hemen hemen her ülkede arttığı söylenebilir. Özetle hem kamu, hem de özel sosyal harcamanın GSYiH içindeki payının yükseldiği anlaşılmaktadır.

Tablo 3: 1980-2015 Dönemini Iç̧eren OECD Ülkelerine Iliş̧kin Toplam Sosyal Harcamanın GSYiH içindeki Payı

\begin{tabular}{|c|c|c|c|c|c|c|c|c|c|c|c|c|c|c|c|c|}
\hline \multirow{2}{*}{ Ülkeler/Yıllar } & \multirow{2}{*}{ Kaynak } & \multicolumn{5}{|c|}{ Toplam sosyal harcamalar } & \multicolumn{5}{|c|}{ Nakdi harcamalar } & \multicolumn{5}{|c|}{ Ayni harcamalar } \\
\hline & & 1980 & 1990 & 2000 & 2010 & 2013 & 1980 & 1990 & 2000 & 2010 & 2013 & 1980 & 1990 & 2000 & 2010 & 2013 \\
\hline \multirow[t]{2}{*}{ AUS } & $\mathrm{mu}$ & 10.27 & 13.13 & 18.24 & 16.71 & 18.11 & 6.09 & 7.19 & 9.99 & 29 & 8. & 4.18 & 72 & 7.89 & 11 & 8.93 \\
\hline & ć & 1.01 & 0.85 & 3.12 & 2.24 & 2.41 & m.d. & 0.01 & 2.52 & 1.55 & 1.56 & i.d. & i.d. & m.d. & id. & \\
\hline \multirow[t]{2}{*}{ AUT } & १u & 21.96 & 23.21 & 25.49 & 27.58 & 27.56 & 16.31 & 16.90 & 17.74 & 18.36 & 18.31 & 5.65 & .99 & 7.24 & 8.40 & 8.49 \\
\hline & 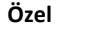 & 2.49 & 2.19 & 1.96 & 1.95 & 1.99 & 1.38 & 1.15 & 0.92 & 0.83 & 0.84 & m.d. & i.d. & m.d. & m.d. & $\mathrm{m} \cdot \mathrm{a}$ \\
\hline \multirow[t]{2}{*}{ BEL } & mu & 23.08 & 24.42 & 23.50 & 28.30 & 29.32 & 17.67 & 16.73 & 15.32 & 17.68 & 18.22 & 5.41 & 61 & 7.31 & 9.85 & 10.38 \\
\hline & Özel & 0.98 & 1.56 & 1.67 & 1.93 & 1.83 & 0.10 & 0.03 & 0.00 & 0.00 & 0.00 & m.d. & 0.00 & 0.00 & 0.00 & 0.00 \\
\hline \multirow[t]{2}{*}{ CAN } & mu & 13.31 & 17.55 & 15.76 & 17.55 & 16.88 & 6.95 & 9.39 & 8.61 & 8.91 & 8.67 & 6.36 & 7.68 & 6.79 & 8.31 & 7.97 \\
\hline & ö & 1.54 & 3.21 & 4.87 & 4.74 & 4.51 & m.d. & m.d. & m.d. & m.d. & m.d. & m.d. & m.d. & m.d. & m.d. & $\mathrm{m} \cdot \mathrm{d}$ \\
\hline \multirow[t]{2}{*}{ DNK } & iu & 20.33 & 21.97 & 23.77 & 28.94 & 29.02 & 10.55 & 11.37 & 11.28 & 13.25 & 13.83 & 9.79 & 9.87 & 10.64 & 13.74 & 13.38 \\
\hline & 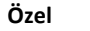 & 5.00 & 4.67 & 3.86 & 4.48 & 4.69 & m.d. & m.d. & m.d. & 2.03 & 2.46 & m.d. & m.d. & m.d. & m.d. & m.c \\
\hline \multirow[t]{2}{*}{ FIN } & & 17.74 & 23.32 & 22.65 & 27.42 & 29.48 & 10.25 & 14.01 & 14.51 & 16.51 & 17.61 & 6.75 & 8.48 & 7.28 & 9.91 & 10.8 \\
\hline & & 0.86 & 1.05 & 1.13 & 1.15 & 1.14 & m.d. & m.d. & m.d. & m.d. & m.d. & m.d. & m.d. & m.d. & m.d. & $\mathrm{m} . \mathrm{c}$ \\
\hline \multirow[t]{2}{*}{ FRA } & & 20.23 & 24.28 & 27.50 & 30.66 & 31.49 & 13.60 & 15.23 & 16.11 & 18.48 & 19.25 & 6.64 & 8.34 & 10.23 & 11.09 & 11.38 \\
\hline & & 0.56 & 1.88 & 2.56 & 3.32 & 3.44 & m.d. & 0.24 & 0.28 & 0.17 & 0.20 & m.d. & 0.00 & 0.00 & 0.04 & 0.0 \\
\hline \multirow[t]{2}{*}{ DEU } & & 21.79 & 21.35 & 25.41 & 25.92 & 24.76 & 14.75 & 13.33 & 15.02 & 14.68 & 13.65 & 7.04 & 7.16 & 9.14 & 10.35 & 10.4 \\
\hline & 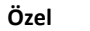 & 2.95 & 3.00 & 2.89 & 3.07 & 3.31 & 1.85 & 1.55 & 1.27 & 1.15 & 1. & m.d. & n.d. & m.d. & i.d. & $\mathrm{m}$. \\
\hline \multirow[t]{2}{*}{ IRL } & & 15.66 & 16.84 & 12.57 & 22.39 & 20.23 & 8.38 & 10.65 & 6.75 & 13.51 & 12.02 & 7.28 & 5.16 & 5.04 & 7.98 & 7.35 \\
\hline & 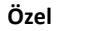 & 23 & 1.40 & 1.25 & 1.83 & 1.96 & m.d. & m.d. & m.d. & m.d. & m.d. & m.d. & า.d. & d. & i.d. & m. \\
\hline \multirow[t]{2}{*}{ ITA } & K & 17.38 & 20.65 & 22.64 & 27.63 & 28.62 & 11.76 & 14.41 & 15.76 & 19.11 & 20.39 & 5.62 & 5.02 & 6.34 & 8.10 & 7.8 \\
\hline & Öz & 8 & 2.03 & 1.62 & 1.35 & 1.35 & 0.78 & 1.47 & 1.11 & 0.69 & 0.64 & m.d. & 3 & m.d. & m.d. & m.c \\
\hline \multirow[t]{2}{*}{ JPN } & K & 10.24 & 11.11 & 16.27 & 22.07 & 23.06 & 5.30 & 5.91 & 8.84 & 11.99 & 12.19 & 4.95 & 4.88 & 7.15 & 9.79 & 10.6 \\
\hline & 0 & 08 & 0.16 & 3.59 & 3.53 & 3.58 & 0.08 & 0.16 & 0.51 & 0.60 & 0.66 & m.d. & m.d. & m.d. & 0.00 & 0.00 \\
\hline \multirow[t]{2}{*}{ KOREA-NS } & $K$ & ר.d. & 2.68 & 4.25 & 8.28 & 9.30 & m.d. & 1.1 & 9 & 1 & .6 & m.d. & 1.5 & 2.3 & 4.9 & 5. \\
\hline & ö & d. & 0.36 & 2.58 & 1.94 & 2.20 & m.d. & 0.3 & 0.7 & 0.5 & 0.6 & m.d. & 0.0 & 0.2 & 0.1 & 0. \\
\hline \multirow[t]{2}{*}{ NLD } & $K$ & 23.26 & 23.99 & 18.40 & 22.09 & 22.88 & 16.69 & 16.48 & 10.46 & 10.89 & 11.80 & 6.06 & 6.32 & 6.62 & 10.09 & 10.2 \\
\hline & ö & 3.84 & 5.70 & 6.85 & 6.96 & 3 & 0.43 & 0.42 & 71 & 0.61 & 0.69 & m.d. & d. & m.d. & m.d. & m. \\
\hline \multirow[t]{2}{*}{ NZL } & K & 16.74 & 20.54 & 18.46 & 20.25 & 19.28 & 11.02 & 14.38 & 10.98 & 10.08 & 9.56 & 5.18 & 5.81 & 7.28 & 9.86 & 9.4 \\
\hline & & 0.07 & 0 & 17 & 46 & 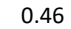 & m.d. & m.d. & m.d. & m.d. & m.d. & m.d. & m.d. & m.d. & m.d. & n. \\
\hline \multirow[t]{2}{*}{ NOR } & amu & 16.12 & 21.55 & 20.40 & 21.92 & 21.77 & 9.46 & 12.89 & 10.96 & 10.93 & 10.84 & 6.66 & 7.79 & 8.84 & 10.36 & 10.4 \\
\hline & & L & 1. & 2.01 & 2.02 & 9 & 0.24 & 1.12 & 24 & 19 & 1.19 & m.d. & i.d. & m.d. & m.d. & $\mathrm{m}$. \\
\hline \multirow[t]{2}{*}{ PRT } & Kamu & 9.51 & 12.22 & 18.51 & 24.48 & 25.50 & 6.50 & 8.00 & 11.44 & 16.32 & 18.38 & 3.02 & 3.77 & 6.47 & 7.49 & 6.62 \\
\hline & & 59 & 0.85 & 1.52 & 1.76 & 93 & 0.23 & 0.22 & 0.39 & 0.27 & 0.28 & i.d. & m.d. & m.d. & m.d. & $\mathrm{m} . \mathrm{c}$ \\
\hline \multirow[t]{2}{*}{ ESP } & $m$ & 14.98 & 19.20 & 19.48 & 25.84 & 26.28 & 10.72 & 13.20 & 12.60 & 16.10 & 17.47 & 4.10 & 5.23 & 6.11 & 8.84 & 8.1 \\
\hline & & .20 & 0.24 & 0.27 & 37 & 0.39 & m.a. & m.d. & m.a. & m.a. & m.d. & m.d. & m.d. & m.d. & m.d. & \\
\hline
\end{tabular}


Tablo 3: Devam

\begin{tabular}{|c|c|c|c|c|c|c|c|c|c|c|c|c|c|c|c|c|}
\hline \multirow[t]{2}{*}{ SWE } & $\mathrm{mu}$ & 24.85 & 27.24 & 26.77 & 26.27 & 27.39 & 12.93 & 15.08 & 13.45 & 11.91 & 12.02 & 11.92 & 10.61 & 11.69 & 13.26 & 14.01 \\
\hline & & 1.07 & 1.16 & 2.45 & 2.97 & 3.58 & m.d. & m.d. & 0.51 & 0.35 & 0.43 & m.d. & m.d. & m.d. & m.d. & m.d. \\
\hline \multirow[t]{2}{*}{ CHE } & & 12.77 & 12.13 & 16.29 & 18.43 & 19.20 & 9.00 & 7.67 & 9.78 & 10.31 & 10.41 & 3.77 & 4.26 & 6.00 & 7.52 & 8.23 \\
\hline & & 1.74 & 4.14 & 6.20 & 6.58 & 6.84 & 1.74 & 3.24 & 5.12 & 5.61 & 5.95 & m.d. & d. & i.d. & m.d. & 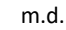 \\
\hline UR & & 3.97 & 5.53 & 7.72 & 12.84 & 13.36 & 2.31 & 3.95 & 4.46 & 8.31 & 8.88 & 1.66 & 1.56 & 3.23 & 4.52 & 4.4 \\
\hline \multirow[t]{2}{*}{ GBR } & & 15.59 & 15.24 & 17.71 & 22.79 & 21.87 & 9.52 & 8.34 & 9.21 & 11.07 & 10.74 & 5.54 & 6.40 & 8.27 & 11.33 & 10.92 \\
\hline & & 3.41 & 4.69 & 7.27 & 5.89 & 5.95 & 0.23 & 0.30 & 0.67 & 0.90 & 0.95 & m.d. & m.d. & m.d. & m.d. & m. \\
\hline \multirow[t]{2}{*}{ USA } & K & 12.84 & 13.17 & 14.25 & 19.35 & 18.82 & 8.22 & 7.51 & 7.32 & 9.61 & 9.25 & 4.62 & 5.44 & 6.78 & 9.59 & 9.4 \\
\hline & Ozel & 4.41 & 7.35 & 8.79 & 10.81 & 11.43 & 0.26 & 0.32 & 0.22 & 0.16 & 0.16 & 0.10 & 0.20 & 0.16 & 0.15 & \\
\hline
\end{tabular}

Kaynak: http://stats.oecd.org/ Erişim tarihi: 21.07.2017, m.d.: mevcut değil.

Tablo 4, 1980-2013 dönemlerini içeren OECD ülkelerine ilişkin Amerikan Doları cinsinden kişi başına düşen toplam sosyal harcama miktarını göstermektedir. Yıllar itibariyle seçilmiş OECD ülkelerinin hepsi, kişi başına düşen toplam sosyal harcama miktarını artırmıştır. Buna ek olarak, Anglosakson ülkelerin kişi başına düşen toplam sosyal harcama miktarı, diğer OECD ülkelerine nazaran görece düşük düzeydedir. Öte yandan, sosyal demokrat ülkelerin kişi başına düşen toplam sosyal harcama miktarı, diğer OECD ülkelerine nazaran görece yüksek düzeydedir. Buna ek olarak, 1980 ve 2015 yılların ait Türkiye'ye ilişkin veriler incelendiğinde kişi başına düşen ayni sosyal harcama miktarı 17 kat, kişi başına düşen nakdi sosyal harcama miktarı 25 kat ve toplam sosyal harcama miktarı ise tam 22 kat yükselmiştir.

Tablo 4: 1980-2013 Dönemini İ̧̧eren OECD Ülkelerine Illişkin Kişi Başına Düşen Sosyal Harcama, Cari Fiyat ve Cari Satın Alma Gücü Paritesi, Amerikan Doları Cinsinden

\begin{tabular}{|c|c|c|c|c|c|c|c|c|c|c|c|c|c|c|c|}
\hline \multirow{2}{*}{ Ülkeler/Yıllar } & \multicolumn{5}{|c|}{ Toplam sosyal harcamalar } & \multicolumn{5}{|c|}{ Nakdi harcamalar } & \multicolumn{5}{|c|}{ Ayni harcamalar } \\
\hline & 1980 & 1990 & 2000 & 2010 & 2013 & 1980 & 1990 & 2000 & 2010 & 2013 & 1980 & 1990 & 2000 & 2010 & 2013 \\
\hline AUS & 1076 & 2326 & 5127 & 7053 & 8480 & 638 & 1274 & 2809 & 3499 & 4193 & 437 & 1014 & 2217 & 3424 & 4183 \\
\hline AUT & 2316 & 4523 & 7535 & 11556 & 13071 & 1721 & 3294 & 5246 & 7695 & 8685 & 596 & 1167 & 2140 & 3518 & 4028 \\
\hline BEL & 2421 & 4652 & 6649 & 11124 & 12715 & 1854 & 3187 & 4335 & 6950 & 7900 & 567 & 1260 & 2067 & 3872 & 4502 \\
\hline CAN & 1594 & 3536 & 4648 & 7098 & 7506 & 833 & 1892 & 2538 & 3603 & 3857 & 761 & 1548 & 2002 & 3363 & 3544 \\
\hline DNK & 2073 & 4126 & 7027 & 12109 & 13260 & 1075 & 2136 & 3335 & 5544 & 6318 & 997 & 1852 & 3146 & 5747 & 6116 \\
\hline FIN & 1617 & 4175 & 5994 & 10507 & 12073 & 934 & 2508 & 3840 & 6326 & 7211 & 615 & 1518 & 1926 & 3797 & 4450 \\
\hline FRA & 1954 & 4271 & 7146 & 11015 & 12356 & 1313 & 2679 & 4186 & 6637 & 7552 & 641 & 1467 & 2659 & 3982 & 4466 \\
\hline DEU & 2538 & 4585 & 6828 & 10467 & 11141 & 1718 & 2863 & 4038 & 5928 & 6144 & 819 & 1538 & 2456 & 4178 & 4698 \\
\hline IRL & 1008 & 2259 & 3722 & 9684 & 9622 & 539 & 1429 & 1998 & 5841 & 5717 & 469 & 692 & 1492 & 3451 & 3495 \\
\hline ITA & 1673 & 3774 & 6031 & 9503 & 10150 & 1132 & 2633 & 4197 & 6574 & 7231 & 541 & 1100 & 1688 & 2784 & 2772 \\
\hline JPN & 906 & 2168 & 4245 & 7484 & 8442 & 468 & 1154 & 2306 & 4064 & 4462 & 438 & 952 & 1866 & 3320 & 3912 \\
\hline KOREA-NS & m.d. & 222 & 818 & 2523 & 3048 & m.d. & 92 & 344 & 941 & 1170 & m.d. & 128 & 409 & 1485 & 1728 \\
\hline NLD & 2463 & 4509 & 5804 & 9891 & 10975 & 1767 & 3098 & 3298 & 4876 & 5662 & 642 & 1188 & 2087 & 4517 & 4912 \\
\hline NZL & 1419 & 3011 & 3963 & 6315 & 7122 & 934 & 2109 & 2357 & 3141 & 3530 & 439 & 853 & 1563 & 3075 & 3491 \\
\hline NOR & 1575 & 3935 & 7506 & 12890 & 14541 & 925 & 2353 & 4034 & 6429 & 7244 & 651 & 1421 & 3252 & 6096 & 6961 \\
\hline PRT & 520 & 1366 & 3304 & 6596 & 7121 & 355 & 893 & 2041 & 4397 & 5132 & 165 & 421 & 1154 & 2019 & 1850 \\
\hline ESP & 1044 & 2595 & 4230 & 8367 & 8636 & 747 & 1785 & 2735 & 5212 & 5741 & 286 & 707 & 1326 & 2861 & 2690 \\
\hline SWE & 2748 & 5468 & 7865 & 10968 & 12342 & 1429 & 3027 & 3951 & 4973 & 5417 & 1319 & 2130 & 3433 & 5535 & 6315 \\
\hline CHE & 1916 & 3203 & 5569 & 9429 & 11393 & 1350 & 2025 & 3344 & 5273 & 6177 & 565 & 1125 & 2052 & 3848 & 4882 \\
\hline TUR & 114 & 323 & 708 & 2056 & 2559 & 67 & 231 & 409 & 1331 & 1701 & 48 & 91 & 296 & 724 & 858 \\
\hline GBR & 1405 & 2671 & 4920 & 8216 & 8619 & 858 & 1461 & 2558 & 3991 & 4232 & 500 & 1121 & 2298 & 4086 & 4303 \\
\hline USA & 1586 & 3113 & 5125 & 9279 & 9838 & 1015 & 1776 & 2634 & 4610 & 4837 & 570 & 1287 & 2438 & 4598 & 4939 \\
\hline
\end{tabular}

Kaynak: http://stats.oecd.org/ Erişim tarihi: 21.07.2017, m.d.: mevcut değil.

Bu bağlamda 1980-2013/2015 dönemi incelendiğinde OECD ülkelerinin kişi başına düşen sağlık harcamalarını, sağlık harcamalarının GSYiH içindeki payını ve sosyal harcamalarını artırdığını ifade edebiliriz. Bununla birlikte, OECD ülkelerinin hemen hemen hepsi sosyal harcamaların GSYiH içindeki payını (Hollanda hariç) artırmıştır. 


\section{Sağlık ve Sosyal Harcamaların OECD Ülkeleri ile Karşılaştırılan Değişim Oranlarına Yönelik Bulgular}

\subsection{Türkiye ve OECD Ülkelerindeki Sağıık Harcamalarının Analizi}

Şekil 1: 1980-2015 yılları arasındaki toplam sağlık harcamasının GSYiH içindeki payının değişim oranı.

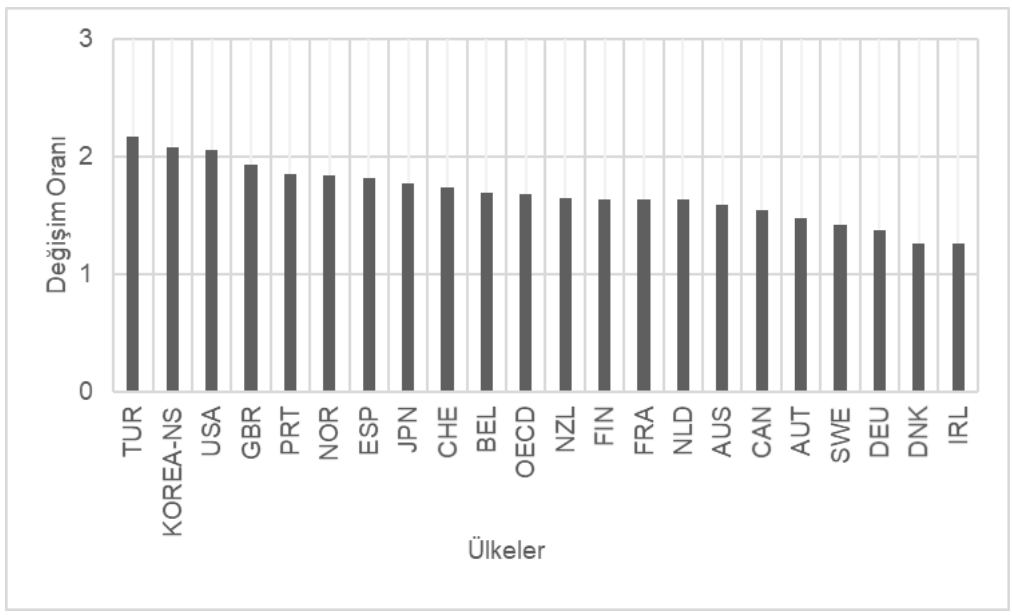

Şekil 2: 1980-2015 yılları arasındaki kişi başına düşen sağlık harcama miktarının değişim oranı.

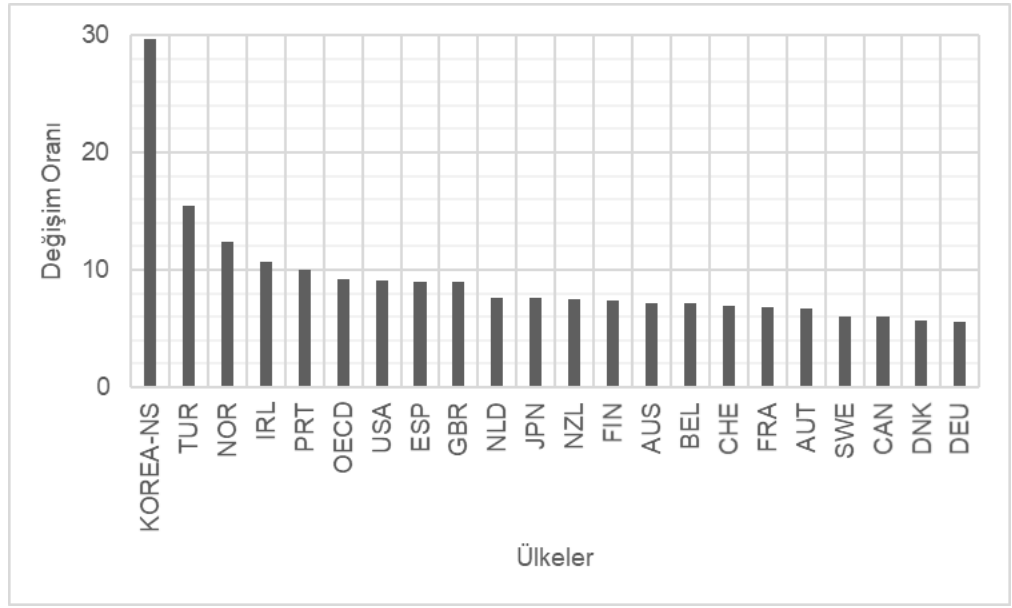

Şekil 1, toplam sağlık harcamasının GSYiH içindeki payının 1980 ile 2015 yılları arasındaki değişim oranını ve Şekil 2 ise, kişi başına düşen toplam sağlık harcama miktarının 1980 ile 2015 yılları arasındaki değişim oranı göstermektedir. Her iki şekilde Türkiye'nin, Güney Kore ile birlikte, seçilmiş OECD ülkeleri ortalamasının üstünde olduğunu ve bu ülkeler içerisinde sağlık harcamalarına ilişkin veriler dikkate alındığında en yüksek sırada yer aldığı görülebilir. 


\subsection{Türkiye ve OECD Ülkelerindeki Sosyal Harcamaların Analizi}

Şekil 3: 1980-2013 yılları arasındaki toplam sosyal harcamanın GSYiH içindeki payının değişim oranı.

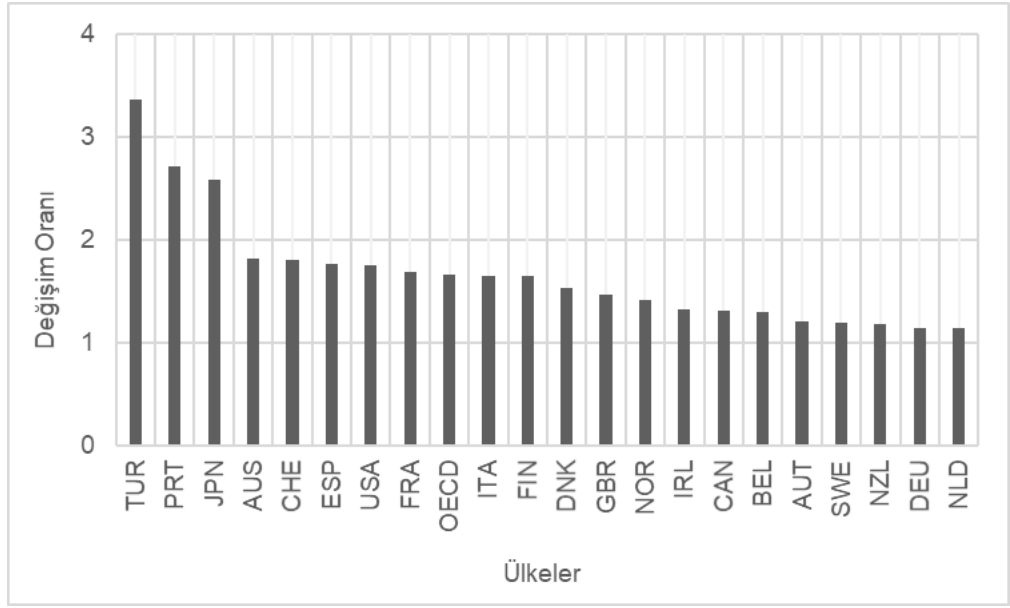

Şekil 4. 1980-2013 yılları arasındaki kişi başına düşen sosyal harcama miktarının değişim oranı.

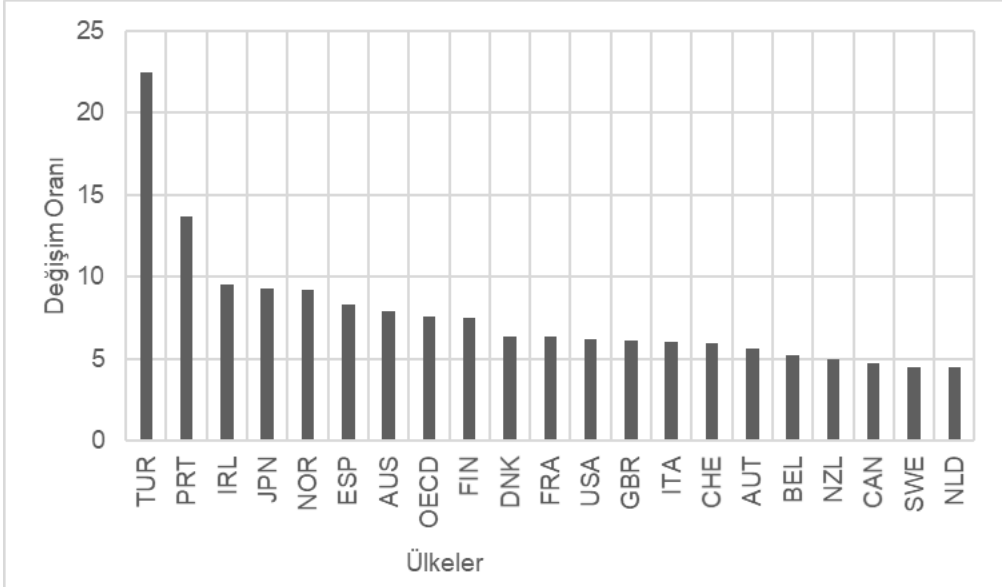

Şekil 3, toplam sosyal harcamanın GSYiH içindeki payının 1980 ile 2013 yılları arasındaki değişim oranı ve Şekil 4 ise, kişi başına düşen toplam sosyal harcamanın 1980 ile 2013 yılları arasındaki değişim oranını göstermektedir. Şekil 3 ve Şekil 4'te, Türkiye'ye ait özel sosyal harcamalara ilişkin verilerin olmamasından dolayı sadece kamu sosyal harcamasına ilişkin verilere yer verilirken, diğer ülkeler özel ve kamu sosyal harcaması birlikte ele alınmıştır. Her iki şekilde de, Türkiye'nin seçilmiş OECD ülkeleri ortalamasının üstünde olduğunu ve bu ülkeler içerisinde sosyal harcamaya ilişkin veriler dikkate alındığında Portekiz ile birlikte en yüksek sıralarda yer aldığı görülebilir. 
Şekil 5. 1990-2013 yılları arasındaki toplam sosyal harcamanın GSYiH içindeki payının değişim oranı.

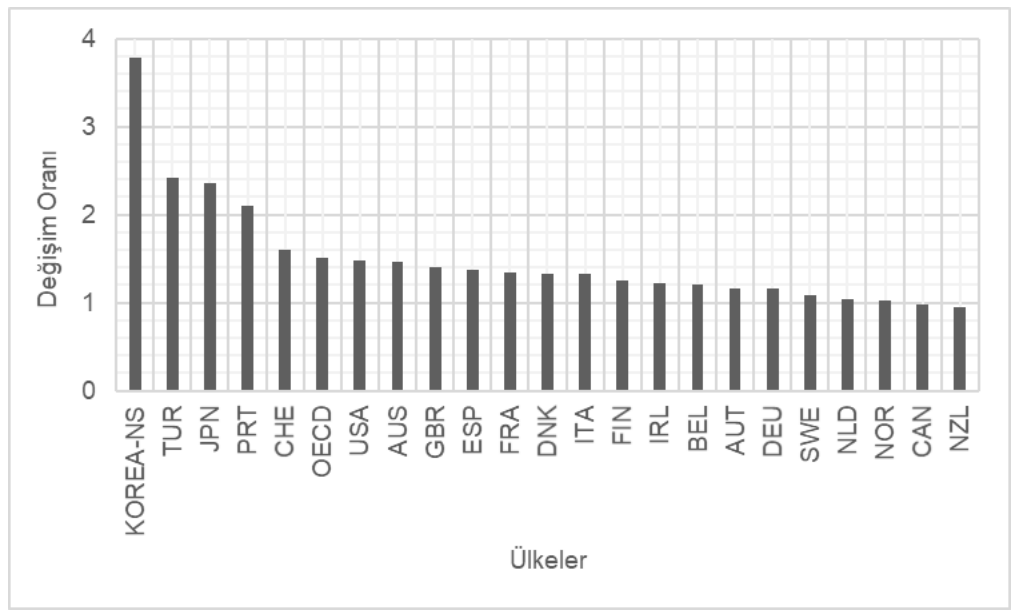

Şekil 6. 1990-2013 yılları arasındaki kişi başına düşen sosyal harcama miktarının değişim oranı.

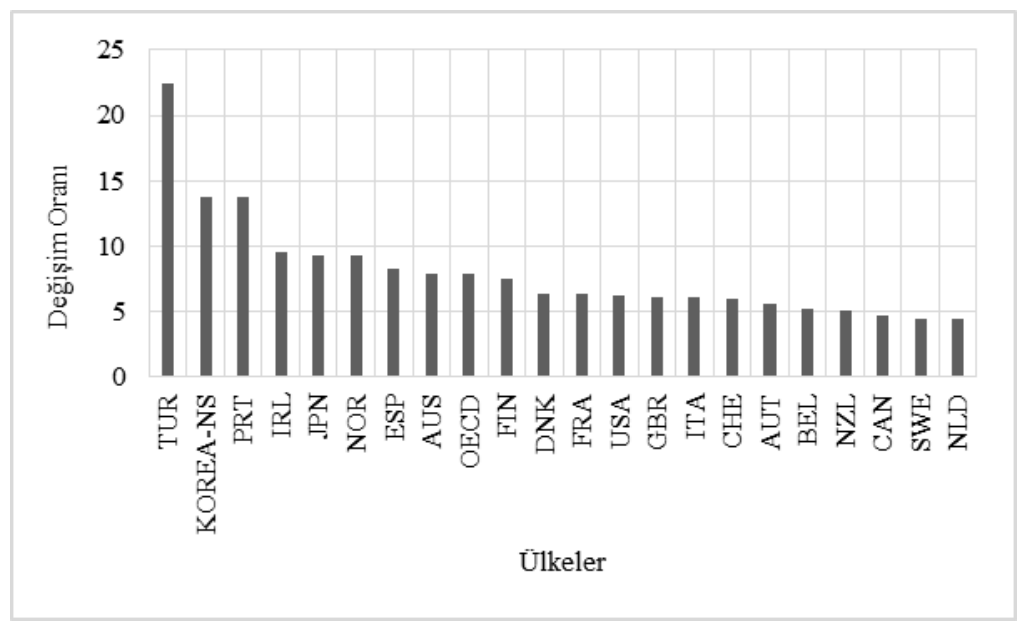

Şekil 5, toplam sosyal harcamanın GSYiH içindeki payının 1990 ile 2013 yılları arasındaki değişim oranı ve Şekil 6 ise, kişi başına düşen toplam sosyal harcamanın 1990 ile 2013 yılları arasındaki değişim oranını göstermektedir. 1980-2013 yılları baz alındığından Güney Kore 1980 yılına ait verisi olmadığı için Şekil 3 ve Şekil 4'de gösterilmemiştir. Ancak veri aralığı, 1990-2013 yıllarını kapsayacak şekilde baz alındığında Şekil 5 ve Şekil 6’daki gibi olacaktır. Aslında bir bakıma, sağlık ve sosyal harcama verilerine ilişkin tablolara ve şekillere bakıldığında, Türkiye ve Güney Kore'nin hem toplam sağlık ve sosyal harcamanın GSYiH içindeki payının 1990 ile 2013 yılları arasındaki değişim oranı, hem de kişi başına düşen harcama miktarının 1990 ile 2013 yılları arasındaki değişim oranı, diğer OECD ülkelerine nazaran daha yüksek olduğunu söyleyebiliriz. 


\section{Değerlendirme ve Tartışma}

İkincil verilerin analizine dayalı tepkisiz tipteki bu araştırmada OECD ülkeleri ile Türkiye'nin sağlık ve sosyal harcamaları karşılaştırmalı biçimde sunulmaya çalışılmıştır. Çalışma sonuçları genellikle daha önceki çalışmaların sonuçlarını destekler niteliktedir. Çalışmanın bir bölümünde ise literatürden biraz daha farklı sonuçlara ulaşılmıştır. Başlangıçta OECD ülkeleri ve Türkiye'yi betimleyen bulgular açıklanmıştır.

Yıllar itibari ile OECD ülkelerinin hepsi ve Türkiye'de toplam sağlık harcamalarının GSYiH içindeki payı artmaktadır. Bu ülkelerin genelde kamu sağlık harcama payları özel sağlık harcamalarına göre daha yüksekti. Sağlık harcamalarına yönelik çalışmalar (Musgrove vd., 2002; Pearson ve Martin, 2005; Moscone ve Tosetti, 2010; Xu vd., 2010; Yardim vd., 2010; Dahl ve van der Wel, 2013; Yıldııım, 2016) bizim bulgularımızla örtüşmekteydi. Aynı zamanda bizim çalışmamızla benzer şekilde literatür, Anglosakson ülkelerin özel sağlık harcama paylarının diğer ülkelere göre arttığını vurguladı (Seshamani ve Gray, 2004; Di Matteo, 2005; Pearson ve Martin, 2005; Nixon ve Ulmann, 2006; Moscone ve Tosetti, 2010).

Kişi başına düşen sağlık harcama miktarlarında da bizim çalışmamız ile diğer çalışmaların durumu ortaktı (Seshamani ve Gray, 2004; Siskou vd., 2008; Xu vd., 2010; Cuckler vd., 2013). Anglosakson ülkelerde diğerlerine oranla özel sağlık harcamalarında kişi başına düşen miktar bizim çalışmamızla paralel biçimde yüksekti (Di Matteo, 2005; Nixon ve Ulmann, 2006; Moscone vd., 2007; Cuckler vd., 2013). Türkiye'nin de kişi başına düşen sağlık harcama miktarı hem kamuda hem özelde hem de toplamda yıllara göre artış göstermişti. Türkiye'den farklı değişkenler temelinde tasarlanan diğer çalışmalar (Yardim vd., 2010; Atun vd., 2013; Kurt, 2015) bizi desteklemekteydi. Bizim tahminimize göre gerçek şu ki kamu, özel ve toplam sağlık harcama kalemlerinde iyi seviyelere ulaşmış hemen hemen bütün ülkeler yüksek ve orta-üst gelirli ülkelerdi. Nitekim yüksek ve orta-üst gelirli ülkeler sağıık harcamalarının kronik hastalıklar, yoksulluk ve halk sağlığı ile yakından ilişkili olduğu iyi biliyordu (Çınaroğlu ve Şahin, 2016; Rezapor vd., 2017; Becchetti vd., 2017; Xu vd., 2018; Liang ve Tussing, 2019).

Neoliberal politikaların ülkelerin sağlık ve sosyal bakım/koruma politikaları ve programları üzerinde olumsuz bir etkiye sahip olduğu söylenebilir. Neoliberal politikalar, sosyal insanın yerine ekonomik insanı öne çıkartmakta, ancak insanlar makine olmanın ötesine geçememektedir. İnsan mekanik değil, organiktir. İnsan bir bireydir ve çevresiyle var olmaktadır. Bu bağlamda, neoliberal politikaların toplum üzerindeki tüm yıkıcı özelliklerini bertaraf etmek için, devletler önlem almaktadır. Ancak devletlerin aldığı önlemler, yani bu korumacı tavrı, neoliberal politikaların bir başka deyişle de IMF ve WB'nin işine gelmemektedir. Tüm bu gelişmelere rağmen, devletlerin bu korumacı tavrı sürdürdüğünü rahatlıkla ifade edebiliriz. Bu devletlerin başında da sosyal demokrat ülkeler gelmektedir.

Önceki çalışmalar (Esping-Andersen, 1990; Ferrera, 1996; Mishra, 1999; Ferrera vd., 2000; Leibfried, 2000; Esping-Andersen, 2002; Buğra ve Keyder, 2003; Yıldırım, 2016) sosyal demokrat devletlerin korumacı tavrı ile ilgili çıkarımlarımızla tutarlı sonuçlar içermektedir. Özellikle Esping-Andersen (1990)'in yaptığı sınıflama bağlamında sosyal demokrat OECD ülkelerinin, Anglosakson OECD ülkelerine göre kamusal alanda kişi başına düşen toplam sağlık ve sosyal harcama miktarının daha yüksek olduğu görülebilir.

Türkiye'de kişi başına düşen ayni, nakdi ve toplam harcama miktarları OECD ülkeleri ile paralel bir şekilde yükselmektedir. Bu noktada literatür bizim tespitlerimizi destekler iken Türkiye'deki çalışmalar (Buğra ve Keyder, 2003; Gökbunar vd., 2008; Toprak, 2015; Yıldırım, 2016; 
Erkul ve Demir-Erkul, 2016; Aydın ve Çakmak, 2017) harcamaların devleti zorlayıcı olduğunu, ekonomik parametre dengelerinde yaşanacak olumsuz bir durumda kamu sosyal harcama alanı bakımından gerilim ve stresin her an yükselebileceğini hissettirmektedir.

Bizim çalışmamızda kamu sosyal harcamalarında Hollanda hariç OECD ülkelerinin GSYiH içindeki payı artmıştı. Türkiye'de OECD ülkeleri gibi aynı çizgiyi takip etmekteydi. Yine sosyal harcama alanlarına yönelik kişi başına düşen miktar OECD ülkeleri ve Türkiye'de artmıştı. Devletin sosyal harcamalarını partizan politikalar, siyaset, vergiler, sanayi, kamu borçları gibi göstergeler üzerinden değerlendiren çalışmalarda (Kittel ve Obinger, 2003; Adema ve Ladaique, 2005; Castles ve Obinger, 2007; Lora ve Olivera, 2007) devletin kasasına giren ek kaynakların sosyal harcama alanlarına yönelik yatırımlar olarak vatandaşa geri döndüğü haliyle kişi başına düşen harcama miktarının yükselebileceği, kamu borçlarının ise sosyal harcamaları azalttığı ifade ediliyordu. Bu yönüyle bizim çalışmamızın literatürdeki çalışmalardan beslendiğini belirtmek yanlış olmayacaktı.

Bu çalışmada ilginç olan Anglosakson ülkelerde kişi başına düşen sosyal harcama miktarının diğer OECD ülkelerine göre daha düşük düzeyde seyretmesiydi. Çalışmanın dikkat çekici diğer bir tespiti ise sosyal demokrat ülkeler için ortaya kondu. Kişi başına düşen sosyal harcama kalemlerinde sosyal demokrat ülkeler diğer OECD ülkelerine göre daha fazla harcama yapmaktaydı. Literatür bizim çalışmamızdan farklı olarak sosyal harcamaların düşük olmasını; kadınlarda sağlık ve eğitim eşitsizliklerine neden olması, özel sosyal harcamaların rolü, politik hakların yapısı, hizmet programlarının dönüşümü gibi konularla birlikte daha detaylı ele almaktadır (Castles, 1986; Pearson ve MarGörtin, 2005; Görg vd., 2009; Dahl ve van der Wel, 2013; Yıldırım 2016, Álvarez-Gálvez ve Jaime-Castillo, 2018). Ayrıca literatürde sosyal harcamaların; sağlık harcaması, engellilik ve dezavantajlı gruplar, göç ve sosyal haklar üzerine etkisini gösteren çaIışmalar (Agovino ve Parodi, 2016; Jaime-Castillo vd., 2016; Otto, 2018) da bulunur.

Diğer taraftan yapılan incelemeler farklılıklar sergilese de Anglosakson ve sosyal demokrat ülkelere yönelik yapmış olduğumuz bu dikkat çekici bildirimler literatür ile uyuşmaktadır (Castles, 1986; Pearson ve Martin, 2005; Görg vd., 2009; Dahl ve van der Wel, 2013). Bu sonuç pek tabi neoliberal ekonomi politikalarını benimseyen ama bir o kadar da vatandaşını piyasanın etkilerinden sakınan sosyal demokrat devletlerin korumacı tavrını açıkça ortaya koyuyordu. Ancak Anglosakson ülkelerde sosyal harcamaların düşük olması bilhassa kadınların sağlık ve eğitim eşitsizlerine maruz kalma konusunu (Dahl ve van der Wel, 2013) yeterince açıklamıyordu.

Türkiye'de 1980 yılından itibaren neoliberal politikaların izdüşümleri görülse de sağıık ve sosyal harcama odaklarında kısıtlama devlet politikasının gündemi değildir. Türkiye'de neoliberal politikalar benimsenirken sosyal devlet olma özelliğinden taviz verilmediği ifade edilebilir. Türkiye'nin, toplam sağlık ve sosyal harcamalarının GSYiH içindeki payının 1980 ile 2013/2015 yılları arasındaki değişim oranı, diğer OECD ülkelerine göre daha yüksekti. Bizim görüşümüzün aksine bazı çalışmalar (Kittel ve Obinger, 2003; Adema ve Ladaique, 2005; Di Matteo ,2005; Castles ve Obinger, 2007; Görg vd., 2009; Moscone ve Tosetti, 2010; Dahl ve van der Wel, 2013) OECD ülkelerinde de kayda değer harcama artışlarının olduğunu gösterdi. Aradaki farkın temel sebebi bizce, diğer çalışmalarda incelemeye Türkiye'nin dâhil edilmemiş olmasıdır. Eğer Türkiye'yi de kapsayan analizler yapılsaydı sonuçların bizi destekleyebileceği kanısındayız.

Türkiye'yi sağlık harcamalarının GSYiH içindeki payında değişim oranı bazında takip eden ülke Güney Kore idi. Sosyal harcamaların değişim oranında ise aynı yıllar arasında takip eden ülke Portekiz idi. Buna ek olarak; Türkiye'de kişi başına düşen toplam sosyal ve sağlık harcama miktarının 1980 ile 2013/2015 yılları arasındaki değiş̧im oranı da diğer OECD ülkelerine göre 
yüksekti. Aynı şekilde kişi başına düşen sağlık harcama miktarının değişiminde Güney Kore; kişi başına düşen sosyal harcama miktarının değişim oranında ise Portekiz Türkiye'nin takipçisiydi.

Çalışma sosyal harcamalar ile ilgili şaşırtıcı başka bir tespit daha yapmıştır. Güney Kore'nin 80 'li yıllara ait sosyal harcama verileri OECD sisteminde yeterli ölçüde gözükmemektedir. Eğer sosyal harcamalar için değerlendirmeye 1990 yılından itibaren başlasaydık 2013 itibari ile Portekiz yerine Güney Kore'nin diğer OECD ülkelerinden daha yüksek sosyal harcama hacmine sahip olduğunu vurgulardık. OECD ya da başka veri tabanlarının desteği ile sağlık ve sosyal harcamalara dönük yapılan çalışmalarda genellikle Portekiz (Hitiris, 1997; Dixon ve Mossialos, 2000; Görg vd., 2009; Dahl ve van der Wel, 2013; Quintal ve Lopes, 2016) değerlendirilen ülkeler arasında yer alsa da Güney Kore'ye özgü yapılan çalışmaları (Hahn ve McCabe, 2006; Song ve Shin, 2014) da gündeme almak gerekir. Türkiye, Güney Kore ve Portekiz'in sağlık ve sosyal harcama kalemlerinin birlikte ve derinlemesine analiz edilmesinin kıymetli veriler sağlayacağını açıkça düşünmekteyiz.

Buna ek olarak, Türkiye'de son yıllarda sosyal harcamalara ilişkin yapılan diğer disiplinlerdeki kuramsal ve uygulamalı çalışmalara da göz atılmıştır. Bu uygulamalı sosyal harcama çalışmalarına ilk olarak Buğra ve Adar (2007) ön ayak olmuştur. Sonrasında araştırmacılar sosyal harcamaları, geleneksel endeksle hesaplanması (Çalışkan, 2012), kamu gelirleri ve dolaylı vergiler (Karanfil ve Özkaya, 2013), yoksulluk oranı (Çelikay ve Gümüş, 2014), gelir dağılımı (ilgün, 2016), iç borç (Bıyıklığlu, 2017), toplam sosyal vergiler ve enflasyon oranı (Kaymaz, 2018) ve ekonomik büyüme (Arısoy vd., 2010; Kolçak ve Kalabak, 2017; Ersin ve Baş, 2019) ile ilişkilendirmişlerdir. Sosyal harcamalara ilişkin kuramsal çalışmalara baktığımızda ise, Yentürk (2009), Uğur ve Bos$\tan$ (2016), Toprak vd., (2016) ve Toprak ve Şataf (2017)'ın çalışmaları ön plana çıkmaktadır.

Öte yandan, Türkiye'nin kişi başına düşen toplam sağlık ve sosyal harcama miktarındaki değişim oranı ve toplam sağlık ve sosyal harcamanın GSYiH içindeki değişim oranı yıllar itibariyle artmasına rağmen, diğer ülkelere kıyasla bizce yeterli gözükmemektedir. Yine de Türkiye'nin sağlık ve sosyal harcama bakımından kat ettiği mesafe göz önünde bulundurulduğunda iyi bir yol benimsendiği söylenebilir.

\section{Sonuç ve Gelecek Çalışmalar}

\subsection{Sinırlılıklar}

Bu çalışma bir takım özellikleri açısından sınırlılıklara sahiptir. Sınırlılıkların ilki, karşılaştırma yapmadan bir ülkeyi ele alarak enine boyuna değerlendirme ile ilgilidir. Karşılaştırma yapmadan tek bir ülkenin sadece farklı değişkenlere göre analizi sağlık ve sosyal harcama kalemlerine yönelik daha detaylı bilgiler sunabilirdi. Ancak bu çalışma; Türkiye'deki sağlık ve sosyal harcama göstergelerinin OECD ülkeleri ile karşılaştırmalı analizini sunarak OECD ülkeleri arasında Türkiye'nin konumunu açık bir şekilde belirlemeyi amaçladı. Diğer sınırlılık, ikincil verilerin güvenilirliğine yönelik araştırmacılarda yaratılan kaygıdır. OECD sistemi ile her yıl OECD ülkeleri kendi verilerini paylaşır. OECD ülkeleri ve Türkiye'nin sistemle paylaştığı veriler bütün ülkelerin kendilerince uygun gördüğü ve analiz ettiği verilerdir. Ayrıca tablolardan da anlaşılacağı üzere söz konusu yıllarda bazı ülkeler OECD sistemi ile kendi verilerini paylaşmadığı için mevcut değil notu düşülmüştür. Son sınırlılık, sosyal hizmet araştırma felsefesinin entelektüel boyutuna yöneliktir. Sosyal hizmet araştırması sosyal sorunların çözümüne yönelik uygulamalı çözümler sunması yönüyle diğer sosyal bilim araştırmalarından ayrılır. Tanımlayıcı, ilişkisel, model üreten, müdahale ortaya koyan, etkinlik test eden çalışmalara sosyal hizmet literatüründe sıklıkla rastlanır. Verileri ilk kaynaktan toplamak önemlidir. Bu durum ile paralel olarak sosyal hizmet literatüründe ikincil 
verilerden yararlanan meta ve sistematik analizlere de rastlamak mümkündür. Kaldı ki sosyal hizmetin mikro, mezzo ve makro olmak üzere üç düzey müdahale boyutu da bulunur. Mikro ve mezzo düzeylerde bireyler, aileler, kronik hastalar, yaşlılar, yoksullar, engelliler, kadınlar, çocuklar gibi risk altındaki nüfus gruplarının sorunları ile çalışılır. Makro boyutta ise sosyal politikalara katkı sağlamak ve sosyal hizmetleri şekillendirecek programları hataya geçirmek hedeflenir. íkincil veriler ile analiz yapmayı, bilhassa sağlık ve sosyal harcama kalemlerini değerlendirmeyi, makro sosyal hizmet adına önemsiyoruz.

\subsection{Uygulamaya Yönelik Bazı Çıkarımlar}

OECD verileri modernleşme politikası olarak sağlık ve sosyal harcama kalemlerinde Türkiye'nin yaptığı harcamaların arttığını ifade etmektedir. Başka çalışmalar Eurostat ve Dünya Bankası verilerini de kullanarak Türkiye'ye özgü sağlık ve sosyal harcamaları raporlayabilir. Ayrıca sosyal harcamalar; sosyal güvenlikten yoksulluğa ve işsizliğe, özürlülükten yaşılığa pek çok farklı harcama kalemini içermektedir. Özellikle sosyal harcamalar için bahsi geçen harcama kalemlerini yıllara göre tek tek derinlemesine ele alan çalışmalarda ülkemizdeki boylamsal değişimleri gözlemlemek adına işlevsel olacaktır.

Incelemeye konu olan tüm ülkeler, hem toplam sağlık ve toplam sosyal harcamanın GSYiH içindeki payı, hem de kişi başına düşen toplam sağlık harcaması ve toplam sosyal harcama miktarını artırmıştır. Bu artışların altında yatan temel sebepler; yeni hastalıkların ortaya çıkması, hastalıkların şekil değiştirmesi, teknolojiyle birlikte artan sağlık masrafları, bireylerin ve devletlerin birey ve toplum sağlığını önemsemeleri, devletlerin sağlıklı bireylere olan ihtiyacı, sosyal yardımların çeşitlendirilerek dağıtılması ve alınması hususunda hak temelli bir anlayışı benimsemesi, engelli, yaşı, çocuk ve kadına yönelik politikaların önemsenmesi, geçmişte olduğu gibi devletlerin ekonomik ve enerji krizlerinden en çok etkilenen dezavantajlı grupları korumak istemesi olabilir.

Bu noktada toplumla sosyal hizmetin temel değerlerinden politik savunuculuğu da değinmek gerekir. Demokratik toplum düzenini oluşturmak, kapsayıcı, destekleyici, ırkçı ya da cinsiyetçi olmayan politikalar ve kurumlar yaratmak hatta sosyal adaleti sağlayabilecek örgütlenme çabaları da sosyal hizmet uzmanlarının önderliğinde başarıya ulaşabilir. Neoliberal bakış açıları odağında sosyal hizmet uzmanlarının rol ve sorumluluklarının gözden geçirilmesi iyi bir başlangıç olabilir.

Son olarak liberal, neoliberal, modernleşme yanlısı politikalara ek, artık Türkiye'de sağlık ve sosyal politika sunumunda postmodern yeni yaklaşımlara yönelmenin altı çizilmelidir. Bu tarz bir yönelim yeni harcama kalemlerinin çeşitlenmesini sağlayacak, gereksinim, hak ve sosyal adalet temelli hatta birey merkezli devlet bakışını aynı anda odağında taşıyacaktır. Neyse ki Türkiye ve Türk Dünyası'nda postmodern yeni yaklaşımların önemini kavrayan ve bu konular ile ilgilenen kayda değer sayıda araştırmacı var. Benzer çalışmalar Türk Dünyası'nın sağlık ve sosyal harcama politikasını belirleme ile gelecekteki araştırmalar üzerinde etkili olabilir. 


\section{Kaynaklar}

Adams, Robert; Dominelli Lena; Payne Malcolm (2009), Social Work: Themes, Issues and Critical Debates, 3. Edition, London: Macmillan.

Adema, Willem; Ladaique Maxime (2005), "Net Social Expenditure, 2005 Edition: More Comprehensive Measures of Social Support", https://www.oecd-ilibrary.org/docserver/358663135802.pdf?expires=1544784204\&id=id\&accname=guest\&checksum=891F79C30533C5AEDFE16AACD28FE28C, (Erişim: 28.11.2018).

Agovino, Massimiliano; Parodi Giuliana (2016), "An Analysis of Italian Regional Social Expenditure on Disability and Other Social Measures: A Spatial Econometric Approach", Applied Spatial Analysis and Policy, C.9, S.4: 549-567.

Ağartan, Tuba (2007), "Sağlıkta Reform Salgını”, (Ed. Çağlar Keyder, Nazan Üstündağ, Tuba Ağartan, Çağrı Yoltar), Avrupa'da ve Türkiye'de Sağlık Politikaları: Reformlar, Sorunlar, Tartışmalar, İstanbul: İletişim Yayınları: 37-54.

Alcock, Pete; Haux Tina; May Margaret; Wright Sharon (2008), The Students Companion to Social Policy, 3. Edition, Oxford: Blackwell.

Alston, Margaret (2007), "Globalisation, Rural Restructuring and Health Service Delivery in Australia: Policy Failure and the Role of Social Work?", Health \& Social Care in the Community, C.15, S.3: 195-202.

Álvarez-Gálvez, Javier; Jaime-Castillo Antonio M. (2018), "The Impact of Social Expenditure on Health Inequalities in Europe", Social Science \& Medicine, C.200, S.5: 9-18.

Arısoy, İbrahim; Ünlükaplan İlter; Ergen Zuhal (2010), “Sosyal Harcamalar ve İktisadi Büyüme İlişkisi: Türkiye Ekonomisinde 1960 - 2005 Dönemine Yönelik Bir Dinamik Analiz", Maliye Dergisi, C.Ocak-Haziran, S.158: 398-421.

Atun, Rıfat; Aydın Sabahattin; Chakraborty Sarbani; Sümer Safir; Aran Meltem; Gürol İpek; Nazlığlu Serpil; Özgülcü Şenay; Aydoğan Ülger; Ayar Banu; Dilmen Uğur; Akdağ Recep (2013), “Universal Health Coverage in Turkey: Enhancement of Equity", The Lancet, C.382, S.9886: 65-99.

Aydın, M. Kemal; Çakmak Eyüp Ensar (2017), "Sosyal Devletin Temelleri”, Bilgi Sosyal Bilimler Dergisi, C.34, S.1: 11-19.

Becchetti, Leonardo, Conzo Pierluigi; Salustri Francesco (2017), "The Impact of Health Expenditure on the Number of Chronic Diseases", Health Policy, C.121, S.9: 955-962.

Bıyıklıoğlu, M (2017), “içç Borçların Sosyal Harcamalara Etkisi: Türkiye Üzerine Bir İnceleme”, Uluslararası Yönetim Eğitim ve Ekonomik Perspektifler Dergisi, 5(2), 45-58.

Buğra, Ayşe; Adar Sinem (2007), "Türkiye'nin Kamu Sosyal Koruma Harcamalarının Karşılaştırmalı Bir Analizi”, https://spf.boun.edu.tr/sites/spf.boun.edu.tr/files/T\%C3\%BCrkiye\%E2\%80\%99nin\%20Kamu\%20Sosyal\%20Koruma\%2OHarcamalar\%C4\%B1n\%C4\%B1n\%20Kar\%C5\%9F\%C4\%B1la\%C5\%9Ft\%C4\%B1rmal\%C4\%B1\%20Bir\%20Analizi\%20\%282007\%29.pdf, (Erişim: 06.01.2020).

Buğra, Ayşe (2015), Kapitalizm, Yoksulluk ve Türkiye'de Sosyal Politika, 7. Baskı, İstanbul: İletişim Yayınları.

Buğra, Ayşe; Keyder, Çağlar (2003), "Yeni Yoksulluk ve Türkiye'nin Değişen Refah Rejimi”, http://www.tr.undp.org/content/dam/turkey/docs/povreddoc/UNDP-TR-new_poverty.pdf, (Erişim: 28.11.2018).

Çalışkan, Zafer (2012), "Refah Devletlerinin Dinamik Dengesi: Sosyal Harcamalar İçin Geleneksellik Endekslerinin Hesaplanması", NEÜ Sosyal Bilimler Enstitüsü Dergisi S.2: 218-239

Castles, Francis (1986), "Social Expenditure and the Political Right: A Methodological Note", European Journal of Political Research, C.14, S.5-6: 669-676.

Castles, Francis, Obinger Herbert (2007), "Social Expenditure and the Politics of Redistribution", Journal of European Social Policy, C.17, S.3: 206-222.

Cuckler, Gigi; Sisko Andrea; Keehan Sean; Smith Shelia; Madison Andrew; Poisal John; Wolfe Christian; Lizonitz Joseph; Stone Devin (2013), “National Health Expenditure Projections, 2012-22: Slow Growth until Coverage Expands and Economy Improves", Health Affairs, C.32, S.10: 1820-1831.

Çelikay, F.; Gümüş, E (2014), “Sosyal Harcamaların Yoksulluk Üzerine Etkileri: Ampirik Bir İnceleme”, Anadolu Üniversitesi Sosyal Bilimler Dergisi, C.19, S.4: 127-138

Çınaroğlu, Songül; Şahin Bayram (2016), "Katastrofik Sağlık Harcaması ve Yoksullaştırıcı Etki", Hacettepe Sağlık Idaresi Dergisi, C.19, S.1: 73-86.

Dahl, Espen; van der Wel Kjetil A (2013), "Educational Inequalities in Health in European Welfare States: A Social Expenditure Approach", Social Science \& Medicine, C.81, S.6: 60-69. 


\section{Eskişehir Osmangazi Üniversitesi ïiBF Dergisi}

Di Matteo, Livio (2005), "The Macro Determinants of Health Expenditure in the United States and Canada: Assessing the Impact of Income, Age Distribution and Time", Health Policy, C.71, S.1: 23-42.

Dixon, Anna; Mossialos Elias (2000), "Has the Portuguese NHS Achieved Its Objectives of Equity and Efficiency?", International Social Security Review, C.53, S.4: 49-78.

Erdem, Nilgün (2010), “Bağımlılığın Yeni Biçimleri Olarak Neoliberal Politikalar: Türkiye Örneği”, Ankara Üniversitesi SBF Dergisi, C.65, S.2: 117-135.

Erençin, Arif; Yolcu Vesim (2008), "Türkiye'de Sağlık Hizmetlerinin Dönüşümü ve Yerinden Yönetim”, Memleket Siyaset Yönetim, C.3, S.6: 118-136.

Erkul, Ercem; Demir-Erkul Fatma (2016), “Enerji Fiyatlarındaki Dalgalanmaların Sosyal Harcamalar Üzerine Etkisi: SHÇEK Özel Örneği”, (Ed. İbrahim Cılga, Ercem Erkul, Buğra Yıldırım, Illkay Başak Adıgüzel), Sosyal Çalışma ve Sosyal Politika Yazıları, Ankara: Bellek Yayınları: 181-195.

Erkul, Ercem; Demir-Erkul Fatma (2019), "Neoliberal Politika Çerçevesinde Türkiye ve Şili'ye İlişkin Gelir Dağılımı ve Yoksulluk İstatistiklerinin İncelenmesi" Sosyoekonomi, C.27, S.39: 11-38.

Erol, Hatice; Özdemir Abdullah (2014), "Türkiye'de Sağlık Reformları ve Sağlık Harcamalarının Değerlendirilmesi”, Sosyal Güvenlik Dergisi, C.4, S.1: 9-34.

Ersin, İrfan; Baş Halim (2019), “Güney Avrupa refah ülkelerinde sosyal harcamalar ve ekonomik büyüme arasındaki ilişkinin incelenmesi", Sosyal Güvenlik Dergisi, C.9, S.1: 193-213.

Esping-Andersen, Gosta (1990), The Three Worlds of Welfare Capitalism, First Edition, Oxford: Polity Press.

Esping-Andersen, Gosta (2002), "Towards The Good Society, Once Again?”, (Ed. G. Esping-Andersen), Why We Need a New Welfare State?, New York: Oxford University Press: 1-25.

Etiler, Nilay (2011), “Neoliberal Politikalar ve Sağlık Emekgücü Üzerindeki Etkileri”, Türk Tabipler Birliği Mesleki Sağlık ve Güven Dergisi, C.11, S.42: 2-11.

Feddersen, J. (2015). Component A: National Accounts. Statistics Denmark: https://www.dst.dk/en/consulting/projects/Israel/ComponentA. (Erişim: 06.01.2020).

Ferguson, Lain; Lavalette Micheal (2006), "Globalization and Global Justice: Towards a Social Work of Resistance", International Social Work, C.49, S.3: 309-318.

Ferrera, Maurizio (1996), "The Southern Model of Welfare in Social Europe", Journal of European Social Policy, C.6, S.1: 17-37.

Ferrera, Maurizio; Hemerijck, Anton; Rhodes, Martin (2000), "Recasting European Welfare States for the 21st Century", European Review, C.8, S.3: 427-446.

Gökbunar, Ramazan; Özdemir Harun; Uğur Alparslan (2008), “Küreselleşme Kıskacındaki Refah Devletinde Sosyal Refah Harcamaları", Doğuş Üniversitesi Dergisi, C.9, S.2: 158-173.

Görg, Holger; Molana Hassan; Montagna Catia (2009), “Foreign Direct Investment, Tax Competition and Social Expenditure", International Review of Economics \& Finance, C.18, S.1: 31-37.

Hahn, Sangjin; McCabe Angus (2006), "Welfare-to-Work and the Emerging Third Sector in South Korea: Korea's Third Way?", International Journal of Social Welfare, C.15, S.4: 314-320.

Harlow, Elizabeth (2003), "New Managerialism, Social Service Departments and Social Work Practice Today", Practice Social Work in Action, C.15, S.2: 29-44.

Harlow, Elizabeth (2004), "Why Don't Women Want To Be Social Workers Anymore? New Managerialism, Postfeminism and The Shortage of Social Workers in Social Services Departments in England and Wales", European Journal of Social Work, C.7, S.2: 167-179.

Hitiris, Theo (1997), "Health Care Expenditure and Integration in The Countries of The European Union", Applied Economics, C.29, S.1: 1-6.

Hugman, Richard (2003), “Professional Values and Ethics in Social Work: Reconsidering Postmodernism?”, British Journal of Social Work, C.33, S.8: 1025-1041.

Jaime-Castillo, Antonio M.; Marqués-Perales Ildefonso; Álvarez-Gálvez Javier (2016), "The Impact of Social Expenditure on Attitudes Towards Immigration in Europe", Social Indicators Research, C.126, S.3: 1089-1108.

Jones, Chris (2001), "Voices from the Front Line: State Social Workers and New Labour", British Journal of Social Work, C.31, S.4: 547-562. 
İlgün, Miraç Fatih (2016), “Kamu Sosyal Harcamalarının Gelir Dağılımı Üzerindeki Etkisi: OECD Ülkelerine Yönelik Panel Veri Analizi”, Dokuz Eylül Üniversitesi Sosyal Bilimler Enstitüsü Dergisi, C.17, S.4: 493-516.

Karanfil, Fatih; Özkaya Fatih (2013), “Dolaylı Vergiler, Sosyal Harcamalar ve Fakirlik: Nasıl Bir İlişki Olabilir?”, Ege Akademik Bakış, C.13, S.3: 337-350.

Kaymaz, Volkan (2018), "OECD Ülkelerinde Sosyal Harcamaların Belirleyicileri”, Gazi Iktisat ve İşletme Dergisi, C.4, S.2: $118-130$

Kazgan, Gülten (2013), Tanzimat'tan 21. Yüzyıla Türkiye Ekonomisi, 5. Baskı, İstanbul: Bilgi Üniversitesi Yayınları.

Kemshall, Hazel (2010), "Risk Rationalities in Contemporary Social Work Policy and Practice", British Journal of Social Work, C.40, S.4: 1247-1262.

Kirkpatrick, Ian (2006) "Taking Stock of The New Managerialism in English Social Services", Social Work \& Society, C.4, S.1: $14-24$.

Kirkpatrick, Ian; Ackroyd, Stephen (2003), "Transforming the Professional Archetype: The New Managerialism in The UK Public Services", Public Management Review, C.5, S.4: 509-529.

Kittel, Bernhard; Obinger Herbert (2003), "Political Parties, Institutions, and the Dynamics of Social Expenditure in Times of Austerity", Journal of European Public Policy, C.10, S.1: 20-45.

Kolçak, Menşure; Kalabak Ali Yasin (2017), "Kısa Dönemde Sosyal Harcamalar ile Ekonomik Büyüme Arasındaki Iliş̧ki, 29/28 OECD Ülkesi için Panel Veri Analizi (1998-2012)”, Gazi Üniversitesi Iktisadi ve Idari Bilimler Fakültesi Dergisi, C.19, S.1: 1-19.

Koray, Meryem (2008), Sosyal Politika, 3. Baskı, Ankara: İmge Kitapevi.

Kurt, Serdar (2015), “Government Health Expenditures and Economic Growth: A Feder-Ram Approach for the Case of Turkey", International Journal of Economics And Financial Issues, C.5, S.2: 441-447.

Leibfried, Stephan (2000), "National Welfare States, European Integration and Globalization: A Perspective for the Next Century", Social Policy \& Administration, C.34, S.1: 44-63.

Liang, Li-Lin; Tussing A. Dale (2019), "The Cyclicality of Government Health Expenditure and Its Effects on Population Health", Health Policy, C.123, S.1: 96-103.

Lora, Eduardo; Olivera Mauricio (2007), “Public Debt and Social Expenditure: Friends or Foes?”, Emerging Markets Review, C.8, S.4: 299-310.

Mishra, Ramesh (1999), Globalization and the Welfare State, United Kingdom: Edward Elgar Publishing.

Moscone, Francesco; Knapp Martin; Tosetti Elisa (2007), “Mental Health Expenditure in England: A Spatial Panel Approach", Journal of Health Economics, C.26, S.4: 842-864.

Moscone, Francesco; Tosetti Elisa (2010), "Health Expenditure and Income in The United States", Health Economics, C.19, S.12: 1385-1403.

Mullaly, Robert (1997), Structural Social Work: Ideology, Theory, and Practice, 2. Edition, Toronto: Oxford University Press.

Musgrove, Philip; Zeramdini Riadh; Carrin Guy (2002), "Basic Patterns in National Health Expenditure”, Bulletin of the World Health Organization, C.80, S.2: 134-146.

Neuman, W. Lawrence (2012), Toplumsal Araştırma Yöntemleri: Nitel ve Nicel Yaklaşımlar, 2. Cilt, (Çev. Sedef Özge), Beşinci Basım, Ankara: Yayınodası.

Nixon, John; Ulmann Philippe (2006), "The Relationship Between Health Care Expenditure and Health Outcomes", The European Journal of Health Economics, C.7, S.1: 7-18.

Oğuz, Şebnem (2012), "Türkiye'de Kapitalizmin Küreselleşmesi ve Neoliberal Otoriter Devletin İnşası”, Türk Tabipler Birliği Mesleki Sağlık ve Güven Dergisi, C.12, S.45-46: 2-15.

Otto, Adeline (2018), "Social Expenditure, Social Rights, and Benefit Receipt as Indicators of Welfare State Generosity: Three Peas in A Pod, or A Different Kettle of Fish Altogether?", International Journal of Sociology and Social Policy, C.38, S.9-10: 851-867.

Parton, Nigel (1994), "'Problematics of Government', (Post) Modernity And Social Work”, British Journal of Social Work, C.24, S.1: 9-32.

Pearson, Mark A.; Martin John P (2005), "Should We Extend the Role of Private Social Expenditure?", https://ssrn.com/abstract=695241, (Erişim: 23.11.2018). 


\section{Eskişehir Osmangazi Üniversitesi ïiBF Dergisi}

Pollack, Shoshana (2010), "Labelling Clients 'Risky': Social Work and the Neo-Liberal Welfare State”, British Journal of Social Work, C.40, S.4: 1263-1278.

OECD (2017), “A System of Health Accounts 2011: Revised edition-2017”, http://dx.doi.org/10.1787/9789264270985en. (Erişim: 06.01.2020).

OECD (2019), Social Expenditure Update 2019, Public social spending is high in many OECD countries, OECD Publishing, Paris.

Quintal, Carlota; Lopes Jose (2016), "Equity in Health Care Financing in Portugal: Findings from the Household Budget Survey 2010/2011", Health Economics, Policy and Law, C.11, S.3: 233-252.

Rezapour, Aziz; Vahedi Sajad; Khiavi Farzad Faraji; Esmaeilzadeh Firooz; Javan-Noughabi Javad; Rajabi Abdolhalim (2017), "Catastrophic Health Expenditure of Chronic Diseases: Evidence from Hamadan, Iran", International Journal of Preventive Medicine, C.8, S.1: 1-8.

Rogowski, Steve (2011), "Managers, Managerialism and Social Work with Children and Families: The Deformation of A Profession?", Practice Social Work in Action, C.23, S.3: 157-167.

Seshamani, Meena; Gray Alastair (2004), "Time to Death and Health Expenditure: An Improved Model for the Impact of Demographic Change on Health Care Costs", Age and Ageing, C.33, S.6: 556-561.

Sharland, Elaine (2006), "Young People, Risk Taking and Risk Making: Some Thoughts for Social Work", British Journal of Social Work, C.36, S.2: 247-265.

Siskou, Olga; Kaitelidou Daphne; Papakonstantinou Vasiliki; Liaropoulos Lycourgos (2008), "Private Health Expenditure in the Greek Health Care System: Where Truth Ends and The Myth Begins", Health Policy, C.88, S.2-3: 282-293.

Song, Eun-Cheol; Shin Young-Jeon (2014), "The Effect of Catastrophic Health Expenditure on the Transition to and Persistence of Poverty in South Korea: Analysis of the Korea Welfare Panel Study Data, 2007-2012", Health Policy and Management, C.24, S.3: 242-253.

Toprak, Düriye (2015), "Uygulamada Ortaya Çıkan Farklı Refah Devleti Modelleri Üzerine Bir İnceleme”, Süleyman Demirel Üniversitesi Sosyal Bilimler Enstitüsü Dergisi, C.21, S.1: 151-175.

Toprak, Düriye; Ağcakaya Serpil; Gül Hüseyin (2016), “Sosyal Devlet Yaklaşımı Açısından Türkiye'de 1980 Sonrası Eğitim Harcamalarının Analizi”, Dokuz Eylül Üniversitesi Iktisadi ve Idari Bilimler Fakültesi Dergisi, C.31, S.1: 123-165.

Toprak, Düriye; Şataf Ceyda (2017), "Türkiye'de Sosyal Belediyecilik Çerçevesinde Sosyal Harcamalar Üzerine Genel Bir Değerlendirme", Sayıştay Dergisi, C.Temmuz-Eylül, S.106: 63-86.

TÜiK. (2019). TÜiK Haber Bülteni: Sosyal Koruma Harcamaları, http://www.tuik.gov.tr/PreTabloArama.do (Erişim: 06.01.2020).

Uğur Alparslan, Bostan Kemal M. (2016), "Sosyal Harcamaların Yerelleşmesi: Sosyal Belediyecilik Uygulamalarının Etkinliği”, Gümüşhane Üniversitesi Sosyal Bilimler Enstitüsü Dergisi, C.7, S.15: 39-59.

Xu, Ke; Saksena Priyanka; Jowett Matthew; Indikadahena Chandika; Kutzin Joe; Evans B. David (2010), “Exploring the Thresholds of Health Expenditure for Protection Against Financial Risk", http://www.who.int/healthsystems/topics/financing/healthreport/19THE-thresv2.pdf, (Erişim: 23.11.2018).

Xu, Yongjian; Wu Na; Fan Xiaojing; Zhang Tao; Zhou Zhongliang; Gao Jianmin; Ren Jianping; Chen Gang; (2018), "Catastrophic Health Expenditure in Households with Chronic Disease Patients: A Pre-post Comparison of the New Health Care Reform in Shaanxi Province, China", PloS ONE, C.13, S.3: 1-13.

Yamatani, Hide; Feit Marvin (2013), “Contemporary Social Policy Analysis Methods: An Incorporation of Ethical Principals and Implementation Processes", Journal of Human Behavior in The Social Environment, C.23, S.7: 817-823.

Yardim, Mahmut Saadi; Cilingiroglu Nesrin; Yardim Nazan (2010), “Catastrophic Health Expenditure and Impoverishment in Turkey", Health Policy, C.94, S.1: 26-33.

Yentürk, Nurhan (2009), "Sosyal Koruma Harcamalarını İzleme Kılavuzu 2009-2010-2011", STK Çalışmaları Eğitim Kitapları Bütçe İleme Dizisi no:3, İstanbul

Yıldırım, Buğra (2016), “Sağlıkta Hizmet Dönüşümü Bünyesinde Harcamaların Hak Temeli”, (Ed. İbrahim Cılga, Ercem Erkul, Buğra Yıldırım, İlkay Başak Adıgüzel), Sosyal Çalışma ve Sosyal Politika Yazıları, Ankara: Bellek Yayınları: 165180.

Yıldız, Özkan (2008), “Küreselleşme, Sağıık ve Toplum”, Gaziantep Tıp Dergisi, C.14, S.1: 30-34. 
Nisan 2020, C. 15, S. 1

\section{Extended Summary}

\section{Turkey's Health and Social expenditures: A retrospective Comparative Study from the Perspective of Social Work}

The beginning of the 1980s marked a period when the understanding of the social state declined, and the liberal economy prevailed under neoliberal policies for both developing and developed countries throughout the world. The social welfare states that enjoyed their golden era between 1945 and 1973 started to question the understanding of the social state in light of the first oil crisis in 1973. The public and private sector economies of these states shrank, and their national and foreign debts increased; meanwhile, the states themselves weakened before the countries supporting neoliberal policies. Thus, neoliberal policies came to the forefront as countries gradually abandoned the social state perspective.

Neoliberal policies shaping the new economic bureaucracy were spread across both developing countries and the Eastern European countries that emerged following the collapse of the USSR. Moreover, the countries adopting neoliberal policies began to steer the national economies of other states through the IMF and the World Bank that were under their control, and the health and social expenditures of the other states became the first expenditure items they influenced negatively.

This paper aims to bring into view practical understandings provided by neoliberal analyses within the scope of health and social expenditures so that social services can function as an interpreter for the components of society by using OECD statistics. It attempts to demonstrate clearly the restricted expenditure items - one of the main characteristics of neoliberal method-using OECD data. We stated the research questions as follows:

1. What are the introductory findings of the OECD countries for the period 1980-2013 / 2015?

2. What is the change rate of health expenditures in Gross Domestic Product (GDP) among OECD countries?

3. What is the change rate of health expenditure per capita among OECD countries?

4. What is the change rate of social expenditures in GDP among OECD countries?

5. What is the change rate of social expenditure per capita among OECD countries?

It is important to remember certain points when adopting a social work perspective among the remaining options. Initially, it is necessary to abide by fundamental ethical values - in other words, rights, justice, and benefit principleswhile making and implementing policies (Yamatani and Feit, 2013) because living with dignity and having social rights are closely associated with the social state despite neoliberal policies (Erkul and Demir Erkul, 2016). In addition, the only factor that should remain the same when changing the service structure and provision is the respect for human dignity among both service providers and beneficiaries as well as the distribution of services according to social state understanding (Yıldırım, 2016). At this stage, social services might influence neoliberal policies because they can control the rights-based provision criteria for social and health expenditures. Nevertheless, Ferguson and Lavalette (2006) indicate that social services might improve people's lives, help them understand and cope with their problems, challenge stigmatization and discrimination, and become part of the social justice struggle in the political context.

Second, many social work researchers have focused on different areas, such as medical welfare, child protection, and women's needs, yet few critical social work researchers consider how regulatory policies and strategies should be provided jointly (Pollack, 2010). Social work plays an important role in responding to the inequalities in health and social expenditures, and this role involves the evaluation of implementation models, policy-making, lobbying, advocacy, and policy-based expenditures at both the national and international levels (Alston, 2007).

Thirdly, policy-makers, professionals, and citizens deal with not only social problems, but also the description and administration of inconvenient or risky social policies. They try to scrutinize the health and social expenditures that have become a problem for others, from their own perspective, rather than remaining silent in social service areas because, social services make a commitment to mediate between individuals and the society (Sharland, 2006) and achieve this commitment by scrutinizing social policies. In this context, it will be necessary to share the points that social work areas can perceive as risk and discuss the indicators or modernization programs while evaluating retrospective and comparative statistics about health and social expenditures. Modernization programs advise turning those who receive services into consumers who can choose and access the services they wish and, thus, support them. The inclusion of consumers into public services as co-producers has increased accessibility to services and ensured that the consumers pay for the time spent on these services, considering the limitation of data resources in the funding of innovations. The main aim here is to shift to people-oriented practices, where consumers are paid directly and individual budgets remain under their own control (Adams et al., 2014: 51) 


\section{Eskişehir Osmangazi Üniversitesi iiBF Dergisi}

In light of these issues, a transformation of information takes place in the social work area with the effect of postmodernism and neoliberal policies. The positive effect of the postmodern approach on the transformation of information in social works can account for the temporary nature of professional knowledge and the transformation of social service intervention into a pluralist structure (Parton, 2004, cited by: Hugman, 2003: 1030). At this stage, public or private organizations are expected to provide health and social services and orient expenditures to the receiver properly and swiftly.

The method of study has focused on a statistical analysis of secondary data from OECD and the technique of quantitative research. The result of health and social expenditures statistics for Turkey and OECD countries are analysed by ratio analysis. The study of a single country would have allowed data analysis in greater detail. However, this work pursues the retrospective and comparative analysis of health and social indicators in Turkey as well as determining the country position among the OECD countries. This comparative study requires the selection of a data set that systematizes the measurement of health and social expenditure indicators in all OECD countries which allows a standardized comparison of health and social expenditure statistics in different OECD countries based on the same measures of expenditure in OECD. In the final analysis, providing data about Turkey's health and social expenditures for the "1980$2013 / 2015$ period « in comparison to OECD countries might facilitate efforts to enlighten the history of expenditures for those who received services in modernization programs in Turkey, with a social work perspective.

OECD data indicate that Turkey's spending in health and social expenditure items increased as a part of its modernization policy. Future studies should investigate and report on the health and social policy expenditures in Turkey using the data provided by Eurostat and the World Bank. Social policy expenditures include several different expenditure items, ranging from poverty to unemployment and from disability to old age. Studies handling the mentioned expenditure items for social policy expenditures in detail according to years will be particularly useful in terms of observing longitudinal changes in our country.

Finally, the importance of turning to new, postmodern approaches in the provision of health and social policy in Turkey, in addition to liberal, neoliberal, and pro-modernization policies, should be highlighted. Such a tendency will contribute to the diversification of new expenditure items and, at the same time, keep needs-, rights-, social justice-, and even people-oriented perspectives of the state in its focus. 